\title{
Taxes, institutions, and innovation: Theory and international evidence
}

\author{
Amar Gande ${ }^{1}$, Kose John ${ }^{2}$, \\ Vinay B. Nair ${ }^{3,4}$ and \\ Lemma W. Senbet ${ }^{5,6}$ \\ ${ }^{1}$ Cox School of Business, Southern Methodist \\ University, Dallas, TX 75275, USA; ${ }^{2}$ Charles \\ William Gerstenberg Professor of Banking and \\ Finance, Stern School of Business, New York \\ University, New York, NY 10012, USA; ${ }^{3}$ The TIFIN \\ Group, Boulder, CO 80302, USA; ${ }^{4}$ Wharton \\ School, Philadelphia, PA 19104, USA; ${ }^{5}$ The \\ William E. Mayer Chair Professor of Finance, \\ Robert H. Smith School of Business, University of \\ Maryland, College Park, MD 20742, USA; \\ ${ }^{6}$ Former Executive Director/CEO, African Economic \\ Research Consortium, Nairobi, Kenya \\ Correspondence: \\ LW Senbet, The William E. Mayer Chair \\ Professor of Finance, Robert H. Smith School \\ of Business, University of Maryland, \\ College Park, MD 20742, USA \\ e-mail: Iwsenbet@umd.edu
}

\begin{abstract}
We develop an international model of the design of institutions for regulating innovative activities of private corporations. Informational limitations faced by the social planner preclude complete contracting with private firms. Corporate innovation creates positive and negative externalities. The social planner in each country takes into account the legal system in place, and designs an umbrella of institutions that include a menu of organizational forms, liability structures, corporate taxes, and subsidies. We show that limited liability may be accompanied by excessive innovation. However, when the nonmonetized benefits are very high, private firms may be too conservative in innovation policies. Firms choose their organizational form and level of innovation consistent with private optimality. With the optimal institutional design for each country, we demonstrate that private innovation choices are aligned with social optimality. In particular, we show that the optimally designed corporate tax rate in each country is a decreasing function of its legal effectiveness. Using data from 63 countries over 2003-2018, we document supporting evidence. MNCs can take advantage of differential liability and corporate tax structures across national boundaries to circumvent institutional design constraints. However, when MNCs generate positive externalities to host countries, their governments may provide subsidies and incentives.
\end{abstract}

Journal of International Business Studies (2020) 51, |4| 3-| 442.

https://doi.org/ | 0. I057/s4 I 267-020-00375- I

Keywords: innovation; multinational corporations; legal systems; organizational forms; externalities; international taxation; institutions; social optimality

\section{INTRODUCTION}

Innovative activity is central to the growth of economies. Innovation in the private sector, both by manufacturing firms and by financial institutions, imposes positive and negative externalities; the social impact of these private firms depends on the sharing rule between their owners and the society at large. This sharing rule is governed by laws, regulations, and institutions in place. The European sovereign debt crises and the global financial crisis have generated extensive debate on the need for financial regulation around the world. At the center of the debate has been how tight financial regulation should be. In fact, a sweeping financial regulation was enacted in the US (the Dodd-Frank Act, 2010). The financial crisis has also drawn widespread public attention to
Received: 11 April 2019

Revised: 1 September 2020

Accepted: 3 September 2020

Online publication date: 18 November 2020 
the negative (and positive) externalities imposed on the society at large by the activities of private firms (banks and corporations). Industrial accidents, such as those by Fukushima Daiichi nuclear power plant and British Petroleum's oil spill, have highlighted the importance of these externalities in a much broader context. More recently, climate change has taken center stage in the debate on such externalities.

A recognition of the large impact of these firms on the society at large, including non-financial claimholders of these firms, have led to renewed calls for stricter regulation of their activities by policy-makers and the government. Examples of such non-financial claimholders include customers, employees, suppliers, warranty holders, insurance holders, legal claimants, and others in the society at large who may hold existing or potential claims against the firms and financial institutions. ${ }^{1}$ Passionate anti-corporation groups have painted a picture of corporations (and banks) as amoral profit-maximizing institutions. ${ }^{2}$ Meanwhile, in mainstream corporate finance, shareholder wealth maximization remains a central paradigm, and corporate governance mechanisms are typically geared toward this private objective. While some have argued that a failure of corporate governance mechanisms has been behind the incentive problems that led to the financial crisis, most analyses now blame the reality that the objectives of private firms (banks and corporations) differ significantly from that of society at large. Even if the corporate governance mechanisms are functioning well for the capital claimants (both equity holders and debt holders), the firms may have undertaken levels of innovation and risks well above what is optimal for society at large. ${ }^{3}$

In this paper, we argue that the above-mentioned misalignment of objectives and the resulting deviation of private firms' risk-taking and innovation from the socially optimal level will depend on several factors; importantly, the legal structure in place, the extent of liability implied by the organizational form of business and the taxation of the enterprise. For example, a corporation's concern for non-financial claimholders that have been injured by a firm is likely to depend on the ability of these claimholders to access courts and sue the corporation. In the United States, where legal structure is well developed, examples of large potential claims held by non-financial claimholders are pervasive. Product liability suits, such as those against Manville Corporation - the asbestos manufacturer (see,
Anderson, 1982); A.H. Robins, maker of the Dalkon Shield contraceptive device; and Dow Corning, maker of silicone breast implants, can potentially generate legal claims against the corporation exceeding the value of its assets and force corporations into bankruptcy.

More recently, as reported in the New York Times on July 12, 2018, Johnson \& Johnson was ordered to pay $\$ 4.69$ billion to 22 women and their families who had claimed that asbestos in the company's talcum powder products caused them to develop ovarian cancer. On climate change, as stated in the Economist on December 8, 2018, a key question is whether international oil companies can reduce greenhouse-gas emissions without gutting their businesses. In fact, on December 3, 2018, Royal Dutch Shell went further than any other oil major company in insisting it could. The firm announced that it would set specific targets for reducing carbon emissions every three to 5 years, with the goal of shrinking its net carbon footprint by about half by 2050. On the other hand, innovation by private firms can also produce large positive externalities. For example, a pharmaceutical company that innovates a cure for cancer or a vaccination for coronavirus (COVID-19) does produce enormous benefits to society, but only a small part of it may be captured in the profits of the innovating firm. We will denote these nonmonetized benefits to society as an important positive externality arising from successful innovation.

From this foregoing discussion, it is clear that the presence of positive and negative externalities will affect the non-financial stakeholders in the society differently from the capital suppliers (debt holders and equity holders) in the firm. In other words, the private firm may optimally choose a level of innovation that is different from the socially optimal level of innovation. In fact, limited liability might be accompanied by excessive innovation by the firm. On the other hand, when the nonmonetized benefits to society are very high, private firms may be too conservative in their innovation policies. In our model, firms choose their organizational form and level of innovation consistent with private optimality. Lack of sufficient information on the part of the social planner would preclude complete contracting and invasive regulation as a way of aligning the privately optimal level of innovation with the socially optimal level of innovation.

Our approach is consistent with the institutional theory proposed by North (1990), Jackson and Deeg 
(2008), and Henisz and Swaminathan (2008), and we ask the following question: Can the social planner in country i take into account the existing legal system in that country, and design supplementing institutions optimally to curtail the distorted incentives of corporations that are harmful to society? The fundamental idea behind institutional theory is that well-designed institutions do matter. In other words, they create the "rules of the game" within which the private firms will choose their organizational form, and consequently an innovation policy that will maximize their private objective (assumed to be the value of the firm). If the social planner for country i has designed the institutions optimally, the innovation policy chosen by the firms in country i will be aligned with the socially optimal innovation policy for country i.

As mentioned above, the social planner starts with the existing legal system of her country. The social planner then designs a menu of organizational forms from which the firms can choose the one that is privately optimal for it. If a firm has chosen a limited liability organizational form, there are two consequences. The firm is entitled to a welldefined limitation of liability that will be described later. In return, the limited liability firm will be obligated to pay a corporate tax at a rate that is optimally determined by the social planner. On the other hand, the institutional design may involve a subsidy from the social planner in cases where the innovation involves large positive externality. Within this institutional structure, the firms in country i will select (1) an organizational form, (2) an innovation policy given its organizational form, both to maximize its private objective of firm value maximization. We will show that when the institutional structure is optimally designed by the social planner in country $i$, the innovation policy in (2) will coincide with the socially optimal innovation policy for country $i$.

In this paper, we focus on the limited liability organization. Limited liability specifies a sharing rule between the non-financial claimholders and the set of all financial claimholders. This in turn affects the private incentives to innovate. In the absence of limited liability, many socially beneficial innovations might be passed up due to the threat of lawsuits while, in the presence of limited liability, the corporation may undertake innovation beyond what is socially desirable. In other words, limited liability may induce innovation level which deviates from social optimality. ${ }^{4}$
We then proceed to examine the role of corporate taxation and subsidies in altering the sharing rule between financial owners and non-financial claimants. In particular, corporate taxation affects a corporation's incentive to innovate through a reduction of its cash flows from a successful innovation. A lower after-tax profit in the successful state reduces the incentives of owners to innovate. Therefore, corporate taxation can be viewed as the price that corporations have to pay for limited liability, and it plays an important role in aligning the interests of non-financial claimholders and the owners of a corporation. ${ }^{5}$

In the framework analyzed here, corporate taxation prevents excessive corporate innovative activity that is socially undesirable. We note that the benefits to corporations from limited liability arise from not being liable to the legal costs that are greater than the corporation value. As the legal structure gets weaker, the benefits of limited liability reduce because the corporation is only held accountable for a smaller fraction of the social cost. Consequently, corporations will not be willing to pay a high tax rate in poor legal structures.

In our framework, we are able to characterize some properties of our optimal institutional design for different countries as a function of the strength of the embedding legal system. In particular, our result is that the optimal corporate tax rates are a declining function of the effectiveness of the legal system. Using archival data from 63 countries over 2003-2018, we find empirical support for this prediction of our model. We conduct several additional tests using different proxies for the strength of the legal system, and show that our main result is robust to the legal proxies that we use. We also document an inverse relationship between corporate taxes around the world and an aggregate legal strength metric. Our relationship is also robust to inclusion of country and year fixed effects.

Moreover, as shown in "The model and framework" section, when the nonmonetized benefits to society are very high, private firms may be too conservative in their innovation policies. In this case, other forms of instruments, rather than, taxes are called for. In this regard, our framework helps us understand the dark and the bright side of activities of multinational corporations (MNCs). On the one hand, the framework provides an explanation for MNC strategies that arbitrage differences in legal liability structures and corporate taxes across national boundaries. On the other hand, MNCs can provide positive externalities to innovating in 
the host countries when the required technology or capacity is not available there. Host countries will provide subsidies and incentives to make it attractive for MNCs to locate in the host country. Such innovation incentives are part of our institutional design.

This paper makes several contributions. First, the paper characterizes certain benefits and costs of corporate limited liability and shows how corporate taxation can be used to mitigate, or even eliminate, the excessive innovation incentives of the limited liability corporation. As a corollary, the paper provides a justification for the double-taxation of corporations. ${ }^{6}$ In this context, corporate taxation can be viewed as the price of corporate limited liability.

Second, the paper generates implications on how optimal corporate taxation is related to the strength of legal regimes and hence the value of limited liability across legal structures. We derive a cross-country equilibrium relationship between corporate taxes and the effectiveness of legal system. We document supporting evidence.

Third, our paper contributes to a better understanding of how institutions matter. Jackson and Deeg (2008) examine the construct of institutions from the comparative capitalism (CC) and international business (IB) perspectives. While there is general agreement that institutions do matter, what is emerging is lack of consensus, both at the conceptual and empirical levels, on how institutions matter (e.g., Jackson \& Deeg, 2008; Eden, 2010; Verbeke, 2019). In our framework, we subdivide the institutional structure to be made up of two components: (1) the legal system of the country under reference, (2) the organizational form menu and the corporate tax rate associated with the limited liability organizational form. Even though the components of the institutional structure are designed to align private innovation with social optimality, we do not endogenize the form of these institutions. However, we do endogenize the liability structure and optimal corporate tax rate for country $i$ as a function of the strength of legal system in that country. In particular, we show that the optimally designed corporate tax rates are a declining function of the strength of the legal systems.

The rest of the paper is organized as follows. In "The model and framework" section we present the innovation policy choice of a private firm in the basic model. In "Corporate limited liability and corporate taxation" section, we analyze the innovation policy in the simple case of an ideally strong legal system. In "Legal systems, institutional design and taxation" section, we investigate the institutional design features, such as corporate taxation, and legal regimes for the alignment of private innovative choices with social optimality. "Legal systems and corporate taxes: cross-country empirical evidence" section provides empirical evidence on the relationship between strength of the legal system and corporate tax rates using archival cross-country data from 63 countries. "Extensions" section discusses some extensions, and "Conclusions" section concludes.

\section{THE MODEL AND FRAMEWORK}

In our framework, the legal system that exists in each country is assumed to be exogenously given. Even though the specific heterogeneity that we model pertains to the legal system in place, we could generalize the existing initial configuration of each economy to pertain to other features of the economy including its political system, the degree of development of its markets, the degree of development of its financial institutions etc. For a given initial state of its institutional development, we ask how supplementary institutions should be optimally designed such that corporate innovation policies are aligned with social goals. In this sense, our analysis goes beyond the fundamental idea that institutions matter. Our social planners design a constellation of interdependent structures and systems within their respective countries that is a function of their existing institutional characteristics.

Consistent with most of the early papers in the Law and Finance literature (La Porta et al. 1997, 1998), we assume that different countries have legal systems of varying strengths. The strength of the legal system in a country is exogenously given and cannot be changed within a short period of time. ${ }^{7}$ However, the supplementary institutional structure is carefully designed by the social planner to align the privately-optimal innovation decisions with social optimality. Here, optimal firm responses to a given institutional construct in the respective country environment is taken into account in the institutional design. ${ }^{8}$

We believe that our framework captures one of the important points of institutional theory highlighted by Henisz and Swaminathan (2008) (see, also Eden, 2010). Moreover, the supplementing institutions are cleverly designed such that the 
firms in country $\mathrm{i}$ respond to that institutional construct in their choice of organizational form and subsequently their innovation policy in a privately optimal manner. However, the innovation policy so chosen would turn out to be aligned with the socially optimal innovation policy for country i. Although our approach of interacting institutions is similar to that in institutional theory (Hall \& Soskice, 2001; North, 1990; Jackson \& Deeg, 2008; Aguilera \& Grogaard, 2019), the focal effect of institutions in our framework is through their effect on the investment, and innovation decisions of firms even though informational constraints preclude complete contracting and invasive regulation, the social planner is able to implement her goals through a well-designed set of interacting institutions. Our approach can be characterized as a "thick" approach in the framework of Jackson and Deeg (2008) in which institutions are designed taking into account country-level heterogeneity and such institutions may influence firm-level innovation policies.

As mentioned above, the social planner starts with the existing legal system of her country. The social planner then designs a menu of organizational forms from which the firms can choose the one that is privately optimal for it. If a firm has chosen a limited liability organizational form, there are two consequences. ${ }^{9}$ The firm is entitled to a well-defined limitation of liability that will be described later. In return, the firm will be obligated to pay a corporate tax at a rate that is optimally determined by the social planner in that country. Within this institutional structure, the firms in country i will select (1) an organizational form, (2) an innovation policy given its organizational form, both to maximize its private objective of firm value maximization. We will show that when the institutional structure is optimally designed by the social planner in country $i$, the innovation policy in (2) will coincide with the socially optimal innovation policy for country $i$.

Thus, in in our model, countries are characterized by differences in their respective legal systems. The social planner of country i takes into account the strength of its legal system $\lambda_{i}, 0<\lambda_{i}<1$. For each country $i$, the social planner designs an optimal institutional configuration. The details of the legal system will be given in the "Legal system" subsection and the design problem will be described in the "Corporate limited liability and corporate taxation" section.
The essential aspects of how the choice of organizational form and corporate taxation interact can be captured in the following simple model.

\section{To Innovate or Not to Innovate}

We use a two-date, single period model with $t=0$ denoting the initial date and $t=1$ the final date. The representative private firm in our economy invests I at date $t=0$ in its project. At this point the firm can choose two alternative methods of implementing the project. It can use the old and tried method or the innovative method. The old and tried method involves an investment of I dollars and it generates cash flows whose discounted present value is I dollars. ${ }^{10}$ On the other hand, the innovative project generates a random cash flow at $t=1$. When the innovation succeeds, which happens with a probability $p$, the resulting cash flow is high and is equal to $\mathrm{H}$. When the innovation fails, which happens with a probability $(1-p)$, the cash flow is low, and is equal to $L$. The probability of the success of innovation, $p$, is uniformly distributed on $[0,1]$ and is common knowledge at $t=0$. However, the realized value of $p$ is privately observed by the firm's insider/manager at $t=1$ before she decides whether to innovate or not. ${ }^{11}$ The value of $p$ is assumed to be not verifiable. ${ }^{12}$ It is assumed that risk neutral valuation is appropriate for our economy. ${ }^{13}$

\section{Non-financial Claimants}

While the total payoffs to the financial claimants (capital suppliers) when the innovation succeeds and fails are respectively $H$ and $L$, the society at large bears externalities from the innovation. Let us assume that the costs that the society bears in the failure state are $C_{L}$ and in the success state is $C_{H}$. In other words, in the bad state the non-financial claimholders bear cost $C_{L}$ while in the good state, the non-financial claimholders bear a cost $C_{H}$. The innovation also has positive externalities. For simplicity, we assume that these positive externalities take the form of benefits to society at large, say to non-financial claimants, equal to $B_{H}$ in the success state and $B_{L}$ (standardized to zero) in the failure state. ${ }^{14}$ Examples of positive externalities could be employment, infrastructure development etc. Importantly, $B_{H}$ cannot be monetized by the private firm (the part of the benefits that can be monetized is already included in $\mathrm{H}$, the cash flows in the success state). The decision-makers in the firm would ignore these nonmonetized benefits $B_{H}$ 
in their decision on whether or not to innovate since these are not part of the profits of the firm.

\section{Legal System}

The non-financial claimants can resort to the legal systems in their respective countries to claim compensation for the social costs $C_{H}$ and $C_{L}$ imposed on society by the firms. To capture this in a simple manner, we denote the strength of the legal system by $\lambda, 0<\lambda<1$. This is the fraction of the social costs $\left(C_{L}\right.$ or $\left.C_{H}\right)$ that the corporation is held accountable for such that it is a liability of the corporation. Thus, $\lambda C_{i}(i=L, H)$ is the maximum compensation that the non-financial claimants are able to recover from the corporate owners through the legal channel. In an "ideal" legal regime, $\lambda=1$, and the firm is held responsible for the total costs, $C_{H}$ and $C_{L}$, imposed on society. However, in an extremely poor legal regime $(\lambda=0)$, the corporation is not held liable for any of the social costs, and the non-financial claimants bear the entire cost of the corporation's activities. In a given legal system $\lambda$ that is in place, the extent to which the firm is actually made to pay up its liability $\lambda C_{i}(i=L, H)$, may further depend on its organizational form and the availability of assets and cash in the firm. A firm that is organized as a limited liability will have its legal liability limited to the extent of cash flows available in the firm. In the success state, the firm is liable for the entire liability, $\lambda C_{H}$, since $H>\lambda C_{H}$. However, in the failure state its legal liability is limited to $L$, the available cash flows (i.e., assuming $\left.L<\lambda C_{L}\right)$.

\section{CORPORATE LIMITED LIABILITY AND CORPORATE TAXATION}

We now consider how in each country $i$, the firm's organizational form affects the innovation policy it chooses to pursue. In this section, we assume that the legal systems are "ideally strong", that is $\lambda_{i}=1$ in all the countries. In the next section, when we analyze the impact of law in the design of taxation, we consider the general case of legal systems of varying strengths. The case of an "ideal" legal system ensures that the non-financial claimants have recourse to the legal system to hold the firm liable for all the social costs, $C_{L}$ or $C_{H}$. To focus our analysis to the interesting scenario described here, we will make the following assumptions.

Assumption 1 (a) $C_{L}>L$, and (b) $C_{H}<H$.
The Assumption 1(a), central to our paper, states that the cash flows $L$ in the low state are insufficient to meet the social costs $C_{L}$ that the non-financial claimants have to bear. This assumption captures scenarios in which the social costs of particular products and the legal liability resulting from them exceed the value of corporate assets in the states of the world in which the innovation fails. Examples include product liability suits mentioned earlier in the introduction where the legal claims exceeded corporation value. The assumption also subsumes scenarios of industrial accidents where both the corporation and the society bear large losses. Examples include large oil spills (e.g., the British Petroleum oil spill) and large chemical accidents (e.g., the Union Carbide Bhopal accident).

The Assumption 1(b) states that social cost $C_{H}$ imposed in the high state is lower than corporation value, $H$. In other words, the corporation has sufficient assets in place to pay out liability claims in the high state. This ensures that the corporate owners have an incentive to undertake projects with a high probability of success. For simplicity, we set $L=0$ in the remaining analysis. This would imply that when the innovation fails, a limited liability corporation would not be required to pay any of its legal liability $C_{L}$ since its available cash flows $L$ happen to be zero. We now characterize the socially optimal innovation policy and compare it that of a limited liability firm.

Our framework is within the existing agency paradigm arising from lack of complete contracting due to informational asymmetries between the private firm and the social planner regarding the success probability of the innovative projects available to the firm. Since the firm has superior information about the technology of innovation, incomplete contracting arises naturally. This precludes reaching socially efficient outcomes through complete contracting or efficient bargaining as envisioned in the Coase theorem (see, Coase, 1960). Later, in his retrospective speech while accepting the Nobel Prize, Coase (1991) presaged the role that regulation and institutions can play in the presence of positive transaction costs.

\section{Social Optimality}

The social planner seeks to maximize the welfare of all claimants, including the nonfinancial ones, in determining whether an innovation should be implemented. 
Proposition 1: Independent of the strength of the legal system $(\lambda)$ in the embedding economy, the socially optimal innovation level is: $p_{s}=\frac{\left(I+C_{L}\right)}{\left(H-C_{H}+B_{H}+C_{L}\right)}$.

\section{Proof See below.}

If an innovation has been implemented, and in the state it succeeds, the social planner adds up the following: the cash flows from the project (the benefits that can be monetized) equal to $H$, social costs $C_{H}$, and nonmonetized benefits $B_{H}{ }^{15}$ If an innovation has been implemented, and in the state it fails, the social planner considers the following: the cash flow from the project equal 0 and the social costs equal $C_{L}$. Therefore, the social planner, who considers all social costs and benefits, as well as all cash flows to the firm, would choose the innovation if and only if its probability of success, $p>p_{\mathrm{s}}$. The cut-off point probability $p_{\mathrm{s}}$ is given by the following equality:

$$
\begin{aligned}
& p_{\mathrm{s}}\left(H-C_{H}+B_{H}\right)-\left(1-p_{\mathrm{s}}\right) C_{L}-I=0 \\
& p_{\mathrm{s}}=\frac{\left(I+C_{L}\right)}{\left(H-C_{H}+B_{H}+C_{L}\right)}
\end{aligned}
$$

Equation (1) characterizes the cut-off probability $p_{\mathrm{S}}$ such that the innovation should be implemented whenever $p>p_{\mathrm{s}}$, where $p$ is the probability that the innovation succeeds. From now on we will denote the cut-off probability $p_{\mathrm{S}}$ as the socially optimal innovation policy.

Private firms may deviate from the above innovation policy if they are focused on the cash flow claims of the financial claimants and do not place adequate weight on the social costs $C_{H}$ or $C_{L}$ or the nonmonetized benefits $B_{H}$. It should be recognized that the social optimality condition is independent of the institutional structures in place: legal structure, tax structure, and organization structure. However, the relative weights that a firm may place on its after-tax cash flows, and the social costs will depend on the tax and legal regimes in place, as well as its liability structure. In the next subsections, we examine the innovation policy that would be implemented by the private firm as a function of its limited liability.

\section{Unlimited Liability}

The owners of an unlimited liability corporation receive the cash flow $\mathrm{H}$ if the innovation succeeds (and have to compensate the social costs of $C_{H}$ ) which happens with probability $p$ but also face the prospect of losing $C_{L}$, the value of legal claims in the low state. This assumes that the corporation owner is personally responsible for the full extent of the legal claims. ${ }^{16}$ Since the owners are liable, they choose to invest if $p\left(H-C_{H}\right)-(1-p) C_{L}>I$. Therefore, the unlimited liability corporation will innovate only when its success probability $p>p_{N}$, where

$$
p_{N}=\frac{\left(I+C_{L}\right)}{\left(H-C_{H}+C_{L}\right)}
$$

Comparing $p_{N}$, the cut-off probability for the unlimited liability firm in Eq. (2) with $p_{\mathrm{S}}$, the socially optimal cut-off probability in Eq. (1) we find that $p_{N}>p_{s}$, since the denominator in Eq. (2) is smaller. Consequently, relative to the socially optimal innovation policy an unlimited liability firm innovates too little. The reason that the unlimited liability corporation is cautious is because it accounts for the potential liability claims via the legal system but does not account for (or internalize) the nonmonetized benefits $B_{H}$ to society that its innovation generates.

\section{Limited Liability}

We now consider the innovation policy of a corporation with limited liability. The owners of a limited liability corporation receive the cash flow $\mathrm{H}$ in case of a successful innovation (and have to compensate the social costs of $C_{H}$ ) with probability $p$. However, the owners of a limited liability corporation can walk away from the legal claims $C_{L}$ by non-financial claimants in case of a failure of an implemented innovation. Therefore, the limited liability firm chooses to innovate if $p\left(H-C_{H}\right)>I$. Equivalently, the limited liability corporation innovates whenever the success probability of its innovation $p$ is such that $p>p_{L}$, where

$$
p_{L}=\frac{I}{\left(H-C_{H}\right)}
$$

The innovation policy of the limited liability corporation differs from the socially optimal policy for two reasons: (1) the limited liability corporation takes advantage of the limitation of its liability in the failure state and ignores the social cost $C_{L}$, and (2) it ignores the positive externalities $\left(B_{H}\right.$, the nonmonetized benefits to society). Examine the following wedge term $\Phi$ : 


$$
\Phi=\frac{\left(H-C_{H}-I\right)}{I}-\frac{B_{H}}{C_{L}}
$$

The first term in $\Phi$ summarizes the value relevance of the innovation to the limited liability firm. It captures the cash flow to the firm in the successful state net of the social costs and the investment outlay required per dollar of investment. This term represents the attractiveness of the innovation to the firm value of the limited liability firm when the project is successful, i.e., it takes into account $\mathrm{H}$, the high profits to the firm minus $C_{H}$, the legal liability transfers required, and I, the required investment. Intuitively, the higher this first term is, the more aggressive is the innovation policy implemented by the limited liability firm for a given value of $B_{H} / C_{L}$.

The second term in $\Phi$ summarizes a benefit-tocost measure of the innovation to society at large. It captures the gains to society from the nonmonetized social benefit of the innovation, and the cost to society in the form of social cost in the failure state arising from limitation of liability. Specifically, the measure is the nonmonetized benefits to society $B_{H}$ per dollar of social cost $C_{L}$ in the failure state arising from the innovation. When the nonmonetized social benefits are high, for a given level of social costs in the failure state, the socially optimal innovation level is more aggressive. On the other hand, for larger values of $C_{L}$, the social planner pursues a more conservative innovation policy, the limited liability firm escapes the social cost $C_{L}$, with the full brunt of this cost being borne by the social planner. Hence, for a given level of firm-value characteristics (represented by the firm term in $\Phi$, such as, $H, C_{H}$, and $I$ ), the socially optimal level of innovation will be more aggressive the higher is the value of $B_{H} / C_{L}$. In this case, $\Phi<0$, and the private firm innovates more conservatively than the socially optimal innovation level.

We formalize the intuition of the foregoing discussion in Proposition 2.

Proposition 2: $p_{L} \leq p_{s}$ if and only if $\Phi \geq 0$. When $\Phi>0$, the limited liability corporation innovates more aggressively relative to the socially optimal level, i.e., $p_{L}<p_{s}$.

\section{Proof See "Appendix".}

Proposition 2 implies that when $\Phi=0$, the limited liability firm would innovate exactly at the socially optimal level, and hence no additional institutional mechanisms are required to achieve social optimality. However, when $\Phi>0(\Phi<0)$, the limited liability corporation will implement an innovation policy that is more (less) aggressive than the socially optimal innovation policy. In both cases (i.e., when $\Phi>0$ and $\Phi<0$ ), the social planner will need to design complementary institutions to align the privately optimal innovation policies with the socially optimal policy.

One particular institutional mechanism that we consider for the case when $\Phi>0$ is corporate taxation. In the case when $\Phi>0$, we have $\frac{\left(H-C_{H}-I\right)}{I}>\frac{B_{H}}{C_{L}}$. Here innovation is privately very attractive, and the limited liability firm innovates too aggressively relative to the socially optimal level. If the social planner levies corporate taxes on $\left(H-C_{H}\right)$, the after-tax profits to the firm decreases, reducing the attractiveness of the innovation to the private firm. Now, if the corporate tax rate is chosen such that $\frac{\left(H-C_{H}\right)(1-T)-I}{I}$ equals $\frac{B_{H}}{C_{L}}$, the privately optimal innovation policy will be equal to the socially optimal innovation policy. The details of this institutional design and the corresponding corporate tax design are given in the "Role of corporate taxation" subsection for $\lambda=1$ case, and in the "Design of corporate taxation" subsection for the case of a general $\lambda$.

When $\Phi<0, p_{L}>p_{s}$, and the limited liability firm would innovate more conservatively than the socially optimal level. In this case, we have $\frac{\left(H-C_{H}-I\right)}{I}<\frac{B_{H}}{C_{L}}$. In other words, given the profits $H$, the required liability transfer $C_{H}$, and the required investment $I$, the innovation is not sufficiently attractive to the private firm compared to its attractiveness to the social planner given its high value of $B_{H}$. In this case when $\Phi<0$, the social planner will have to design an appropriate set of institutions that will make the innovation attractive to the private firm. Based on the measure of attractiveness of the innovation $\frac{\left(H-C_{H}-I\right)}{I}$, the social planner may implement a set of institutions to increase the value of $\frac{\left(H-C_{H}-I\right)}{I}$ to the private firm. This can be done through an increase in $\mathrm{H}$, a decrease in $C_{H}$, or a decrease in I such that $\frac{\left(H-C_{H}\right)-I}{I}$ equals $\frac{B_{H}}{C_{L}}$ so as to align the privately optimal innovation policy with the socially optimal innovation policy.

We will consider three types of institutional mechanisms: (1) direct subsidy to augment the profitability $\mathrm{H}$ in the success state of the innovation, (2) a partial or full limitation of legal liability imposed on the private firm in the success state and/or the failure state of the innovation, and (3) an investment subsidy such that at the point of 
Table 1 Numerical calibration

\begin{tabular}{|c|c|c|c|c|c|c|c|c|c|c|c|}
\hline & 200 & 300 & 400 & 500 & 600 & 700 & 800 & 900 & 1000 & 1100 & 1200 \\
\hline 0 & $(0,0)$ & $(1,0)$ & $(2,0)$ & $(3,0)$ & $(4,0)$ & $(5,0)$ & $(6,0)$ & $(7,0)$ & $(8,0)$ & $(9,0)$ & $(10,0)$ \\
\hline 100 & $(0,1)$ & $(1,1)$ & $(2,1)$ & $(3,1)$ & $(4,1)$ & $(5,1)$ & $(6,1)$ & $(7,1)$ & $(8,1)$ & $(9,1)$ & $(10,1)$ \\
\hline 200 & $(0,2)$ & $(1,2)$ & $(2,2)$ & $(3,2)$ & $(4,2)$ & $(5,2)$ & $(6,2)$ & $(7,2)$ & $(8,2)$ & $(9,2)$ & $(10,2)$ \\
\hline 300 & $(0,3)$ & $(1,3)$ & $(2,3)$ & $(3,3)$ & $(4,3)$ & $(5,3)$ & $(6,3)$ & $(7,3)$ & $(8,3)$ & $(9,3)$ & $(10,3)$ \\
\hline 400 & $(0,4)$ & $(1,4)$ & $(2,4)$ & $(3,4)$ & $(4,4)$ & $(5,4)$ & $(6,4)$ & $(7,4)$ & $(8,4)$ & $(9,4)$ & $(10,4)$ \\
\hline 500 & $(0,5)$ & $(1,5)$ & $(2,5)$ & $(3,5)$ & $(4,5)$ & $(5,5)$ & $(6,5)$ & $(7,5)$ & $(8,5)$ & $(9,5)$ & $(10,5)$ \\
\hline 600 & $(0,6)$ & $(1,6)$ & $(2,6)$ & $(3,6)$ & $(4,6)$ & $(5,6)$ & $(6,6)$ & $(7,6)$ & $(8,6)$ & $(9,6)$ & $(10,6)$ \\
\hline 700 & $(0,7)$ & $(1,7)$ & $(2,7)$ & $(3,7)$ & $(4,7)$ & $(5,7)$ & $(6,7)$ & $(7,7)$ & $(8,7)$ & $(9,7)$ & $(10,7)$ \\
\hline 800 & $(0,8)$ & $(1,8)$ & $(2,8)$ & $(3,8)$ & $(4,8)$ & $(5,8)$ & $(6,8)$ & $(7,8)$ & $(8,8)$ & $(9,8)$ & $(10,8)$ \\
\hline 900 & $(0,9)$ & $(1,9)$ & $(2,9)$ & $(3,9)$ & $(4,9)$ & $(5,9)$ & $(6,9)$ & $(7,9)$ & $(8,9)$ & $(9,9)$ & $(10,9)$ \\
\hline 1000 & $(0,10)$ & $(1,10)$ & $(2,10)$ & $(3,10)$ & $(4,10)$ & $(5,10)$ & $(6,10)$ & $(7,10)$ & $(8,10)$ & $(9,10)$ & $(10,10)$ \\
\hline
\end{tabular}

For a given set of values of $I=100, C_{H}=100, C_{L}=100$, we vary $B_{H}$ on the vertical axis from 0 to 1000 (in increments of 100 ), and we vary $H$ on the horizontal axis from 200 to 1200 (also in increments of 100 ) separately. We then calculate the two terms of the wedge $\Phi$ where Term $1=\frac{\left(H-C_{H}-I\right)}{I}$ and Term $2=\frac{B_{H}}{C_{L}}$. The bolded cells in the matrix above denote $\Phi>0$, i.e., Term $1>$ Term 2 .

investing the private firm has to invest only a fraction $\left(1-\alpha^{*}\right)$ of the required investment, and the social planner provides an investment subsidy of the amount $\alpha^{*} I$ in the innovation. We will show that the cost to the social planner in the implementation of institutions (1), (2), and (3) will be different, and that in all three cases, the subsidy amounts will be smaller than $B_{H}$, the nonmonetized benefits to society. The details of the implementation of these different institutional mechanisms are discussed in the "Institutional design when $\mathrm{B}_{\mathrm{H}}$ is high" subsection.

\section{Numerical Calibration}

A simple numerical calibration will be useful to understand the interaction of the relative magnitudes of $H, B_{H}$ and $C_{L}$ and their impact on $\Phi$. For a given set of values of $I$ and $C_{H}$, we vary $H$ and $B_{H}$ separately. We compute the corresponding values of Term 1 and Term 2, where Term $1=\frac{\left(H-C_{H}-I\right)}{I}$ and Term $2=\frac{B_{H}}{C_{I}}$. The highlighted cells in Table 1 denote $\Phi>0$, i.e., Term $1>$ Term 2 .

When the nonmonetized social benefits $\left(B_{H}\right)$ are low relative to the social costs $\left(C_{L}\right)$, conditional on a failed innovation, Term 2 is small and the corresponding socially optimal policy will be less aggressive (i.e., a high value for $p_{\mathrm{s}}$ ). On the other hand, when Term 1 is high, the limited liability firm finds the innovation attractive due to the high value of $\mathrm{H}$ (net of $C_{H}$ and $I$ ), and pursues an aggressive innovation policy using a low value for $p_{L}$. As can be seen by comparing the corresponding numbers in Tables 1 and 2, whenever $\Phi>0, p_{L-}$ $<p_{\mathrm{s}}$, the limited liability firm pursues an aggressive innovation policy relative to the socially optimal one.
The foregoing analysis has implications for the innovation policy and regulatory rules that we might find in different industries with high and low expected values for $B_{H}, C_{H}$ and $C_{L}$. For example, consider innovations in the nuclear industry. Based on historically well-known nuclear accidents, an argument could be made that the values of $C_{H}$ and $C_{L}$ are likely to be high. The Chernobyl nuclear accident is estimated to have exposed 10 million people to nuclear radiation in the surrounding countries with a social cost of roughly $\$ 700$ billion over the past 30 years. See Samet and Seo (2016). ${ }^{17}$ Of course, nuclear energy also bestows enormous benefits to society as a clean source of energy with relatively low emissions of greenhouse gases. Taking into account the resulting high expected value $B_{H}$ several governments have used various policies to encourage innovation in this industry. For example, in the U.S., in addition to being able to operate as a limited liability corporation, the PriceAnderson Act (Public Law 85-256) limits liability from nuclear accidents for a private company to an amount of $\$ 12.6$ billion (as of 2011). ${ }^{18}$ This represents a substantial limitation of liability for the firm, compared to the potential social costs of a nuclear accident. In some other countries (e.g., China, Russia, India, South Africa), the social planner runs the nuclear industry and decides on the innovation policy.

Now we provide an example of an industry with potentially large values of $B_{H}$, nonmonetized expected benefits to the society. In the pharmaceutical industry, firms that innovate procedures and medicines that cure devastating diseases are able to realize profits equal to fraction of the social benefits that derive from the innovation. As an example, 


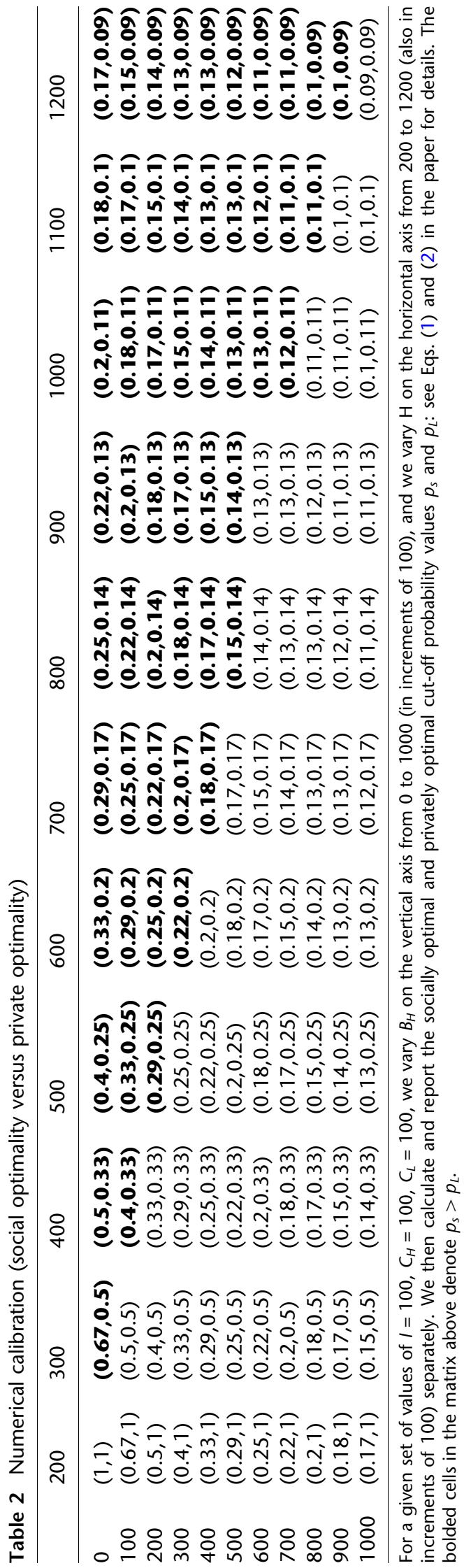

consider the case of a cure for river blindness by the pharmaceutical giant Merck. ${ }^{19}$ Merck, initially provided Mectizan ${ }^{\circledR}$ at a low price to patients in affected countries. Later, Merck started a program of providing the medication free of charge in all the developing countries, thereby protecting about a billion people in the world who are at risk. It is estimated that the foregone revenues from this program during 2005-2011 is US\$3.8 billion (see, for details, Hernando, Colwell \& Wright, 2016). In the pharmaceutical industry, the nonmonetized part of the social benefits $\left(B_{H}\right)$ is often high, and it is a function of the legal infrastructure in that economy that protects property rights.

So far our analysis has focused on the effects of the organizational structure on the innovation policy choices by private firms. We now consider the role of corporate taxes and subsidies in aligning private innovative choices with socially optimality, and how they interact with the legal structures across countries.

\section{The Role of Corporate Taxation}

We examine the role of corporate taxation in mitigating the conflict between the private objectives of the limited liability corporation and that of the society at large. We show that corporate taxation affects a corporations' incentive to innovate by reducing its cash flows from a successful innovation. Therefore, corporate taxation can be viewed as the price that corporations have to be pay for limited liability.

Corporate taxation introduces an additional claimholder (the government) to the corporations' cash flows and hence alters the sharing rule between the corporate owners and the non-financial claimholders. Let the corporate tax rate be $T$. When the innovation succeeds, the corporate owners now only receive $\left(H-C_{H}\right)(1-T) .{ }^{20,}{ }^{21}$ In the failure state, the owners of the limited liability corporation can walk away from any claims exceeding cash flows by non-financial claimants and do not pay any taxes.

Therefore, in the presence of taxation, the limited liability corporation chooses to invest if

$$
p\left(H-C_{H}\right)(1-T)-I \geq 0
$$

With corporate taxation, the limited liability corporation implements innovations whenever its success probability $p>p_{T}$, where the project has a non-negative NPV. 


$$
p_{T}=\frac{I}{\left(H-C_{H}\right)(1-T)}
$$

Comparing Eq. (3) with Eq. (5), it can be seen that $p_{T}$ is greater than $p_{L}$ for any positive corporate tax rate $T$, since the denominator in Eq. (5) is smaller than that in Eq. (3). In other words, for any $T>0$, the firm innovates less aggressively relative to the taxless scenario. ${ }^{22}$ This incentive to reduce innovation now can now counterbalance the incentive to increase innovation due to corporate limited liability. The tax rate, $\mathrm{T}$, can then be chosen such that $p_{T}$ is equal to $p_{\mathrm{S}}$, the socially optimal innovation level. Proposition 3 (see below) characterizes such an optimal tax rate $\mathrm{T}^{*}$. When $\Phi>0$, there is a wedge between the private benefit-cost ratio of the financial claimholders and the social benefit-cost ratio of the non-financial claimholders.

When $\Phi>0$, based on Proposition 1, we know that the innovation rate of the limited liability firm is more aggressive than the socially optimal level. Hence, a socially optimal tax rate $T^{*}$ would equate the innovation level of a firm which has to pay the corporate tax rate to the socially optimal level, i.e., $p_{T}$ in Eq. (5) would equal $p_{S}$ in Eq. (1). Such a tax rate $T^{*}$ has a simple characterization.

Proposition 3: For $\Phi>0$ and a corporate tax rate of $T^{*}=\left[1-\frac{p_{L}}{p_{s}}\right]=\frac{\phi p_{L}}{\left[1+\frac{I}{C_{L}}\right]}$ the innovation policy of the corporation is identical to the socially optimal innovation policy. This tax rate $T^{*}$ is increasing in $\Phi$ and $\mathrm{C}_{L}$. This tax rate $T^{*}$ is decreasing in $\mathrm{p}_{L}$ and $\mathrm{B}_{H}$.

Proof See "Appendix".

Policy Remarks Based on Proposition 2, we know that in the absence of taxes, the limited liability firm innovates more relative to the socially optimal level, i.e., $p_{L}<p_{S}$. Furthermore, since $p_{L}>0$ and $p_{S}>0$, we can see that, based on Proposition 3, that $T^{*}>0$ and $T^{*}<1$. The optimal rate of taxation $T^{*}$, which is applied to the profits in the successful state, alters the ex ante innovation incentives of limited liability corporations to be in line with social optimality. The role of corporate taxation can be viewed in the same manner as the government taking claims in the private firms in the global financial crisis. The government, in exchange for bailing out failing financial institutions, is known to have taken equity-like claims, such as preferred stock and warrants, as a mechanism for repaying the tax payer. In this respect, we wish to make two observations. First, taxation of profitable states works in a fashion similar to holding equity or warrants in the private firms in a setting of ex post resolution of crisis. Second, corporate taxation has ex ante incentive effects, since as we show, it can play a role in realigning the incentives of private firms with the goals of the government. Interestingly, taxation plays such a role even in good times, and unlike equity claims in the bailout schemes, it does not entail voting rights for the government. Thus, incentives are realigned in the right way without mandating specific innovation levels through invasive regulation.

Proposition 3 also implies that the optimal corporate tax rate is a declining function of $B_{H}$, the nonmonetized social benefits of a successful innovation. The social planner may choose to encourage innovation on the part of private firms in certain sectors by providing sector-specific tax incentives. This can be done in several ways. Examples include sector-specific depreciation tax shields, research and development tax credits, and energy investment tax credits. These features in the tax code essentially lower the corporate tax rate for firms in certain sectors from the baseline economy wide tax rate.

Institutional Design When $\boldsymbol{B}_{\boldsymbol{H}}$ is High and $\Phi<0$ When $B_{H}$, the nonmonetized benefits to society is very high, the private firm innovation policy is less aggressive than the socially optimal innovation policy, i.e., $p_{N}>p_{s}$. The reason for the deviation of $p_{N}$ from $p_{\mathrm{s}}$ is clear from a comparison of $p_{N}$ in Eq. (2) with $p_{s}$ in Eq. (1). ${ }^{23}$ While the social planner takes into account $B_{H}$, the nonmonetized social benefits for computing $p_{s}$, the private firm does not. Therefore, $p_{N}>p_{s}$. One possible institutional mechanism that can be used by the social planner is to augment the profits $H$ from a successful innovation by providing a subsidy $(S)$ to the firm. That is, the firm receives $(H+S)$ when the innovation succeeds. If the social planner wishes to fully align the innovation policy of the private firm (with unlimited liability) with the socially optimal policy, the subsidy has to be set equal to $B_{H}$.

A direct subsidy equal to $B_{H}$ is not the only mechanism to align the incentives of the private firm with social optimality. In our framework, we 
will design alternative institutional mechanisms for limiting liability for the private firm to change its innovation incentive. When combined with these mechanisms, the social planner can reduce the direct subsidy required for incentivize alignment. The appealing feature of these alternative mechanisms is to reduce the resource requirement associated with direct subsidies.

In many countries, the social planner has competing demands for the limited resources of the economy and may not be able to subsidize private firms to the tune of $B_{H}$, especially in the case of innovations in which the nonmonetized benefits are very high. In the remainder of the section, we will consider design of institutions by the social planner such that the subsidy to the private firms is combined with different types of limitation of legal liabilities and/or investment subsidy by the social planner in the innovation.

Now we consider the case of a limited liability firm when $\Phi<0$. From the discussion in the "Limited liability" subsection, we know $p_{L}>p_{s}$, and the limited liability firm would innovate more conservatively than the socially optimal level. One possible solution is to supplement the profits $\mathrm{H}$ with a subsidy $S^{*}$ in the successful state such that $\frac{\left(H+S^{*}-C_{H}\right)-I}{I}$ equals $\frac{B_{H}}{C_{L}}$. Such a subsidy $S^{*}$ will make the innovation more attractive to the limited liability firm, and its innovation policy $p_{L}$ will be more aggressive. With a subsidy $S^{*}, p_{L}$ will be equal to $p_{s}$. We characterize the optimal amount of the subsidy $S^{*}$ required to align the innovation policy of the limited liability firm with that of the socially optimal one. $^{24}$

Proposition 4: For the case when $\Phi<0$ the subsidy $\mathrm{S}^{*}$ required is given below:

$$
S^{*}=\frac{\left[\frac{B_{H}}{C_{L}}-\frac{\left(H-C_{H}-I\right)}{I}\right]}{\left[\frac{1}{C_{L}}+\frac{1}{I}\right]}=\frac{-\phi}{\left[\frac{1}{C_{L}}+\frac{1}{I}\right]}>0
$$

With this subsidy $S^{*}$, the innovation policy of the limited liability corporation is identical to the socially optimal innovation policy. $S^{*}$ is strictly less than $\mathrm{B}_{H}$, the subsidy required in the case of the unlimited liability firm.

Proof See "Appendix".

Policy Remarks In the case of an unlimited liability firm, aligning innovation incentives requires a subsidy equal to the full extent of the nonmonetized benefits derived from the innovation. In the case of a high $B_{H}$ innovation, the subsidy required may be higher than the resources available to the social planner. Through an appropriate combination of legal institutions and subsidies, the social planner is able to achieve the innovation alignment using a more modest subsidy.

Can the social planner do even better? It turns out that the social planner has the option of fully or partially limiting the liabilities of the private firm associated with $C_{H}$, the social cost in the successful state. In other words, over and above the limitation of liability in the failure state associated with the limited liability organization form, the social planner can exempt the private firm from some or all of the liability arising from a successful innovation. A well-known example is the Price-Anderson Act (Public Law 85-256) in the United States. This law limits liability from nuclear accidents for a private company to an amount of $\$ 12.6$ billion (as of 2011), even when the assets of the company far exceed the social cost.

Proposition 5: For the case when $\Phi<0$ and the limited liability firm is given additional limitation of liability in the successful state equal to be a fraction $\mathrm{f}(0<f<1)$ of the social cost $\mathrm{C}_{H}$, the subsidy $\hat{S}$ required is given below:

$$
\hat{S}=S^{*}-(1-f) C_{H} .
$$

With this subsidy $\hat{S}$, the innovation policy of the limited liability corporation is identical to the socially optimal innovation policy.Moreover, we have $\hat{S}<S^{*}<B_{H}$.

\section{Proof See "Appendix".}

Policy Remarks With an additional limitation of liability for the private firm, the social planner is able to achieve the alignment of innovation policy of the limited liability firm with a smaller subsidy $\hat{S}$ than that would be required for a limited liability firm without this additional limitation of liability. Propositions 4 and 5 highlight the complementary role of legal institutions in incentive alignment by combining them with taxes and subsidies.

Moreover, the social planner can use other legal institutions in the case of high $B_{H}$ innovations to augment their attractiveness to the private firm, in addition to the limitation of liabilities that we discussed above. Making suitable changes in patent 
laws, trademark laws, and other property rights regulations can effectively increase $\mathrm{H}$ (perhaps at the expense of reducing $B_{H}$ ). This would increase $\Phi$ for that innovation and decrease $p_{L}$ such that the private firm would pursue a more aggressive innovation policy. Examples in the area of pharmaceutical innovations include lengthening patent protection period and weaker pricing regulation of high $B_{H}$ products.

When $\Phi<0$, we know that $p_{L}>p_{s}$ and the institutions designed by the social planner has to provide additional incentives for the private firm to implement the innovation. When the expected profitability of the innovation is not sufficiently attractive to the private firm, the firm shies away from implementing the innovation. This results in a conservative innovation policy compared to the socially optimal policy. The social planner has another important institutional mechanism to incentivize the private firm. It can effectively subsidize investments in a variety of ways, such as subsidizing infrastructure development and human capital development. This is a pervasive institutional feature of many emerging economies. It is also found in specific large innovations in infrastructure construction around the world.

In our model, when $\Phi<0, p_{L}>p_{s}$. Recall $p_{L}=\frac{I}{\left(H-C_{H}\right)}$. The design of investment subsidy involves the social planner contributing a fraction $\alpha^{*}$ of the investment I required at the point of the implementation of the innovation. The fraction $\alpha^{*}$ is chosen optimally by the social planner such that $p_{L}\left(\alpha^{*}\right)=\frac{I\left(1-\alpha^{*}\right)}{\left(H-C_{H}\right)}$ is equal to $p_{s}$.

Proposition 6: For the case when $\Phi<0$ we have $\mathrm{p}_{L}>p_{s}$. A fraction $\alpha^{*}$ of the required investment I is provided by the social planner at the point of implementing the innovation. When $\alpha^{*}=1-\frac{p_{s}}{p_{L}}$, the innovation policy of the limited liability corporation is identical to the socially optimal innovation policy.

Proof See "Appendix".

Policy Remarks In our framework, investment subsidy by the social planner refers to the following institution. The total investment required for the innovation is I dollars. At the point of deciding whether or not to implement the innovation with $\Phi<0$, the social planner can provide assistance of value $\alpha^{*}$ I to the private firm such that the remaining required investment is only $\left(1-\alpha^{*}\right)$ I. Here, the social planner is not seeking ownership in the innovation such that it is entitled to $\alpha^{*}\left(H-C_{H}\right)$ of the profits. In fact, the innovating firm gets to keep the entire profits of $\left(H-C_{H}\right)$. In this respect, the institutional arrangement of investment subsidy is different from the state-owned enterprises that are prevalent in many countries, such as China, UAE, Russia, Saudi Arabia, and India. Here are several mechanisms by which the social planner can implement investment subsidy in socially beneficial innovations undertaken by private firms. An important example would be allowing the private firm to access free of charge the proprietary knowledge gained from costly R\&D undertaken by government agencies.

A second common example is for the social planner to invest in costly infrastructure development and human capital development that private firms can access in order to reduce the required investment outlay. It should be noted that providing an investment incentive of $\alpha^{*}$ I reduces the direct subsidy required to be a fraction of $B_{H}$. In cases in which $\Phi<0$, we have $\alpha^{*} I<I<B_{H}$. As in the case of Propositions 5 and 6 , the social planner is able to reduce the subsidy required by influencing the investment incentives of the private firm directly.

\section{LEGAL SYSTEMS, INSTITUTIONAL DESIGN AND TAXATION}

We have so far assumed an "idealized legal system" $(\lambda=1)$. In this section, we highlight the role of legal strength in altering the sharing rule between firm owners and other stakeholders. In particular, we analyze the general case of a legal system $\lambda, 0 \leq \lambda \leq 1$ in the embedding economy. Thus, we will characterize the corporate innovation policies and the optimal tax structure as a function of the legal system $\lambda$.

\section{Social Optimality}

Since the social planner seeks to maximize the welfare of all claimants, any payoffs that the nonfinancial claimants receive through the legal structure are simply transfers and do not affect the optimality of the social planners' problem. The legal structure impacts the social planner's problem only through the corporation's innovation choices which in turn may be influenced by the payoffs to nonfinancial claimholders. Thus, the socially optimal innovation policy is the same as that we derived in the previous section, and all projects 
with probability of success, $p>p_{S}$, should be accepted where $p_{S}$ is given by the following equality.

$$
\begin{aligned}
& p_{s}\left(H-C_{H}+B_{H}\right)-\left(1-p_{s}\right) C_{L}=I \\
& p_{s}=\frac{C_{L}+I}{H-C_{H}+B_{H}+C_{L}}
\end{aligned}
$$

\section{Limited Liability}

We now consider the innovation policy of a corporation with limited liability. The owners of a limited liability corporation face the prospect of gaining $\left(H-C_{H} \lambda\right)$ in case of a successful innovation. However, the owners of a limited liability corporation can walk away from any claims by nonfinancial claimants in case of innovation failure. Therefore, the limited liability corporation chooses to innovate whenever the success probability $p\left(H-C_{H} \lambda\right)>I$. Therefore, the limited liability corporation implements all innovations with success probability $p>p_{L}(\lambda)$, where

$$
p_{L}(\lambda)=\frac{I}{H-C_{H} \lambda}
$$

The analysis of the innovation policy of the limited liability firm is parallel to that in the previous section. The only generalization is that the legal liability of the private firm is $\lambda C_{H}$ in the success state and $\lambda C_{L}$ in the failure state of the innovation. The value of limited liability to a private firm in a weak legal regime would only be a fraction $\lambda$ of its value in a strong legal regime. This consideration will affect the interaction of limited liability with corporate taxation in affecting the innovation incentives of the private firm.

\section{Design of Corporate Taxation}

We now proceed to examine the role of law in the design of corporate tax and the equilibrium social impact of corporations. Firm owners benefit from limited liability as it allows them to walk away from the social costs they impose in excess of the corporation cash flows (corresponding to the low state in the model considered). However, in the presence of corporate taxation, this benefit comes at a price. In a regime with legal strength $\lambda$ and corporate $\operatorname{tax} T$, the owners of a limited liability corporation receive $\left(H-\lambda C_{H}\right)(1-T)$ when the innovation succeeds and 0 in the low state. Therefore, the limited liability corporation chooses to innovate whenever the success probability
$p\left(H-\lambda C_{H}\right)(1-T)>I$. Thus, the limited liability corporation implements all innovations with success probability $p>p_{T}(\lambda)$, where

$$
p_{T}(\lambda)=\frac{I}{\left(H-\lambda C_{H}\right)(1-T)}
$$

As the strength of the legal regime increases, the threat of being held responsible for negative externalities increases. Limited liability, thus, provides greater benefits now, and consequently corporations are willing to pay a higher tax for limited liability.

The optimal tax rate would be able to induce the limited liability firm to innovate according to the socially optimal innovation policy given by Eq. (6) (i.e., align the innovation policy of the limited liability firm's innovation policy with the socially optimal innovation policy).

Proposition 7: The optimal corporate tax rate $\mathrm{T}_{s}(\lambda)$ is the tax rate that aligns private innovation policy to be at the socially optimal level. It depends on $\lambda$, the strength of the legal regime, and is characterized by:

$$
T_{S}(\lambda)=1-\frac{p_{L}(\lambda)}{p_{S}}=1-\frac{I\left(H-C_{H}+B_{H}+C_{L}\right)}{\left(H-C_{H} \lambda\right)\left(I+C_{L}\right)} .
$$

Proof See "Appendix".

Policy implications Based on Proposition 2, we know that in the absence of taxes, the limited liability firm in each country i innovates more relative to the socially optimal level, i.e., $p_{L}<p_{S}$. In the general case of a legal system $\lambda, 0<\lambda<1$, by comparing Eqs. (7) and (3), it is easy to see that $p_{L}(\lambda)<p_{L}$. Hence, it follows that $p_{L}(\lambda)<p_{S}$. Furthermore, since $p_{L}(\lambda)>0$ and $p_{S}>0$, it is easy to see based on Proposition 7 that $T_{S}(\lambda)>0$ and $T_{S}(\lambda)<1$. The proposition above states that the tax rate can be set to the socially desirable tax rate and corporations with limited liability innovate at the socially optimal levels.

Following Proposition 8, it is useful to note an important implication of our framework for which we provide some supporting empirical evidence in the next section.

Proposition 8: The socially optimal corporate tax rate $\mathrm{T}_{s}(\lambda)$, that induces the limited liability firm to innovate according to the socially optimal innovation policy, is a decreasing function of the legal strength in that country, $\lambda$. 


\section{Proof See "Appendix".}

The socially optimal tax rate $T_{s}(\lambda)$, that would induce the socially optimal innovation level, is decreasing with the legal strength. This result follows from the ability of the legal regime to hold the firm responsible for negative externalities in the good state. In other words, law and taxes act as potential substitute instruments for the social planner. In other words, the tax penalty that needs to be imposed on the limited liability firms to curb their excessive innovation (compared to the socially optimal benchmark) is smaller in a stronger (higher $\lambda$ ) legal system.

Proposition 9: Given the socially optimal tax rate $T_{s}(\lambda)$, firms would choose the limited liability organizational form to maximize their after-tax firm value anticipating that they would subsequently implement the socially optimal innovation policy.

\section{Proof See "Appendix".}

Thus far, we have focused on the institutional dimensions, such as taxation and legal regimes, across countries and how that might affect innovation policies in their respective countries. We next build on our framework to draw implications for firm innovation behavior across national boundaries. In addition to MNC strategies taking advantage of differences in taxation and legal regimes, we also examine the effect of subsidies and incentives for MNC formation and investment behavior.

\section{Implications for Multinational Corporations}

Thus far, our analysis has examined representative firms operating in their respective jurisdictions and legal regimes. We have shown that the optimal tax rates, which align private innovation decision with social optimality, vary depending on the quality of legal regimes. In the framework of institutions and innovation that we have presented, we want to explore the likelihood of formation of MNCs with subsidiaries in host countries different from the home country of the MNC. ${ }^{25}$

Let us consider an innovation in the host country that has a high $B_{H}$, the nonmonetized social benefit and hence $\Phi<0$. In this case, we know from Proposition 2 that there will be underinvestment in the innovation even by the limited liability firms in that country. There are several mechanisms the host-country social planner can use to encourage innovation in these technologies with a high $B_{H}$.
Among them are provision of subsidies, limitation of liabilities, and investment subsidies for local private firms in the host country as we discussed in the "The institutional design when $\mathrm{B}_{\mathrm{H}}$ is high" subsection.

However, these incentives mechanisms will not be viable if the required technology and/or the organizational, managerial, and human capital skills are not yet readily available in the hostcountry economy. In some cases, the required investment capital is in short supply. In this case, the required capital, technology, and management knowledge have to be transferred from abroad (Bawlya, 2006). In this case, the social planner in the host country can provide various investment incentives to the MNC which has access to the required financial capital, technology and organizational capital (as discussed in the "The institutional design when $\mathrm{B}_{\mathrm{H}}$ is high" subsection and Propositions 4, 5 and 6). These incentives can take several forms, such as, subsidizing infrastructure, subsidizing programs for development of requisite skills in the host country (e.g., see Liu, 2008), providing regulatory concessions and various tax incentives to a multinational firm. ${ }^{26}$ As a result, the MNC can expedite the pace of innovation in the host country consistent with the objectives of the social planner. It can also create other positive externalities, such as employment creation and growth.

Even though the host country implements incentive schemes to attract the MNC to invest and innovate in the host country, it should be noted that it may not guarantee the creation of positive externalities as expected (see, Narula, 2002). The superior technology of the MNC may not always create the full extent of the nonmonetized social benefit $B_{H}$ which may require a positive spillover effect (see, Malik, Rehman, Ashraf \& Abbas, 2012). The ability of the host country to capitalize the full extent of the positive externality may depend on its "absorptive capacity", a concept developed and advocated by Cohen and Leventhal (1990). Absorptive capacity represents the ability of the host country to recognize the value of newly acquired technology and knowledge and its ability to assimilate such knowledge in the innovative activity of the host country.

So far we have discussed the bright side of MNCs. However, there is a dark side to the MNCs. Even when $\Phi>0$ and the host country does not provide subsidies and incentives, the MNC might find it attractive to set up subsidiaries in host countries 
that have desirable institutional structures. For example, suppose the host country has a lower tax rate than the home country. In this case, the MNC can engage in a variety of ways to minimize its tax burden in the home country. ${ }^{27}$ Through various transfer pricing and profit shifting arrangements, the MNC is able to take profits and realize its taxable income in a low-tax jurisdiction. It can also move highly profitable innovative activity abroad to lower tax countries.

In addition to tax arbitrage, the MNC can also arbitrage differences in legal institutions between the home country and the host country to its advantage. For example, assume that the MNC is located in a country with a strong legal system, say $\lambda=1$. The host country has a weak legal system, say $\lambda=0.2$. In this case, by using appropriate interjurisdictional litigation strategies, the MNC may be able to limit its legal liability to $0.2 C_{H}$ instead of $C_{H}$. This may also provide an additional incentive for the MNC to move part of its operations to the host country. In addition, since the MNC is only held accountable for $20 \%$ of the social cost $C_{H}$, it may overinvest in projects that produce excessive social costs in the host economy (e.g., environmental pollution) and in activities characterized by lax regulation and weak labor laws.

In our framework, the institutional design implemented by the social planner in country i becomes less effective due to tax avoiding investment strategies unless counter-acting policies are implemented. The resulting implication is that governments should pro-actively close such loopholes. Residually, this calls for increasing the statutory tax rate, such that even after implementing its tax minimizing strategies, the MNC does pay an effective tax rate that equals $T_{s}(\lambda)$ as specified in Proposition 7.

\section{LEGAL SYSTEMS AND CORPORATE TAXES: CROSS-COUNTRY EMPIRICAL EVIDENCE}

In this section, we use archival data from 63 countries over 2003-2018 to provide cross-country evidence relating the corporate tax rates to the strength of the legal system. One of our central predictions is the negative relationship between the strength of the legal systems and the corporate tax rates across national boundaries (see Proposition 8).

\section{Data and Variables}

The primary data for our empirical analysis is from the World Business Environment Survey (WBES) conducted by the World Bank from 63 countries (see Djankov, La Porta, Lopez-de-Silanes \& Shleifer, 2003). ${ }^{28}$ We also use the KPMG corporate tax database, ${ }^{29}$ the World Bank's World Development Indicators (WDI) database, the International Monetary Fund (IMF)'s World Economic Outlook (WEO) database, and the Global Innovation Index database. For robustness checks, we have been able to secure another data source (with some time variation) from another World Bank survey conducted in multiple years on measures of legal effectiveness that includes our original set of countries.

To measure the strength of the legal system, we utilize four different measures of judicial efficiency in resolving business disputes, especially in the absence of formal contracts. We use them to proxy for the ease with which non-financial stakeholders can resort to the legal channel for any negative externalities imposed by a corporation on them.

The first measure captures the extent to which the country's legal system is honest and uncorrupt in resolving business disputes (variable: hon_unc). The second measure captures how affordable the legal system is in resolving business disputes (variable: affordable). The third measure deals with whether the court system is consistent in resolving business disputes (variable: consistent). The fourth measure assesses the extent of public confidence in the legal system (variable: confidence). In particular, this measure is intended to capture the extent to which the country's legal system will uphold contracts and property rights in a business dispute.

These four measures are based on the World Business Environment Survey (WBES) conducted by the World Bank, where questionnaires were answered by managers of small firms (below 50 employees) in these countries. We normalize each of these measures to derive a measure between 0 and 1, and then create an index (Legal) that averages these four measures of legal strength so that it is also between 0 and 1 . Our evidence is based on the sign and magnitude of the coefficient of Legal in an ordinary least-squares regression in Eq. (10) described below.

We utilize corporate tax information for the sample of 165 countries from the KPMG database. ${ }^{30}$ The tax rates are from the KPMG's website and their tax rates are checked regularly by KPMG member firms. Their corporate tax rate data are available on an annual basis starting from 2003. The sample period for our analysis is 2003-2018. See https:// home.kpmg/vg/en/home/services/tax1/tax-tools- 
Table 3 Sample countries

This table below lists all the 63 countries included in our sample

\begin{tabular}{lll}
\hline Argentina & Georgia & Poland \\
Bangladesh & Ghana & Portugal \\
Bulgaria & Guatemala & Romania \\
Bolivia & Honduras & Russian Federation \\
Brazil & Croatia & Senegal \\
Botswana & Hungary & Singapore \\
Canada & Indonesia & El Salvador \\
Chile & India & Slovenia \\
China & Italy & Sweden \\
Cote d'lvoire & Kazakhstan & Thailand \\
Colombia & Kenya & Trinidad and Tobago \\
Costa Rica & Lithuania & Tunisia \\
Czech Republic & Mexico & Turkey \\
Germany & Malawi & Tanzania \\
Dominican Republic & Malaysia & Uganda \\
Ecuador & Namibia & Ukraine \\
Egypt, Arab Rep. & Nigeria & Uruguay \\
Spain & Pakistan & United States \\
Estonia & Panama & Venezuela, RB \\
France & Peru & South Africa \\
United Kingdom & Philippines & Zambia \\
\hline
\end{tabular}

Table 4 Summary statistics

\begin{tabular}{|c|c|c|c|c|c|}
\hline Variable name & Obs & Mean & SD & Min & Max \\
\hline Corporate tax rate & 861 & 26.61 & 6.31 & 9.00 & 42.00 \\
\hline Legal & 861 & 0.41 & 0.19 & 0.08 & 0.96 \\
\hline Hon_Unc & 861 & 0.39 & 0.24 & 0.00 & 1.00 \\
\hline Affordable & 861 & 0.47 & 0.22 & 0.00 & 1.00 \\
\hline Consistent & 861 & 0.34 & 0.23 & 0.00 & 1.00 \\
\hline Confidence & 861 & 0.42 & 0.22 & 0.00 & 1.00 \\
\hline Lagged Ln (GDP) & 861 & 25.85 & 1.77 & 22.21 & 30.60 \\
\hline Lagged GDP growth rate & 861 & 3.89 & 3.72 & -17.67 & 19.68 \\
\hline Year & 861 & 2011.31 & 4.31 & 2004 & 2018 \\
\hline
\end{tabular}

This table reports the summary statistics of the variables used in this study. Hon_Unc captures the extent to which the legal system is honest and uncorrupt in resolving business disputes. Affordable measures how affordable the legal system is in resolving business disputes. Consistent measures the extent to which the country's court system is consistent in resolving business disputes. Confidence measures the extent to which the country's legal system will uphold contracts and property rights in a business dispute. The variables are described in more detail in the paper in the "Legal systems and corporate taxes" section.

and-resources/tax-rates-online.html for details. We run the following regression:

$$
\text { CorporateTaxRate }_{i, t}=\alpha+\beta \text { Legal }_{i, t}+\gamma X_{i, t}+\epsilon,
$$

where Legal measures strength of the legal system as described above, and $X_{i . t}$ refers to the following control variables: (a) Lagged $\operatorname{Ln}(G D P)$ : Lagged value of natural log of a country's Gross Domestic Product (GDP), measured in U.S. dollars from the WDI database, (b) Lagged GDP Growth Rate, measured as a percent from the WDI database, (c) Lagged Debt/ $G D P$, government gross debt as a percentage of GDP (see, Gan \& Qiu, 2019) from the WEO database, and (d) Year: to capture any time trend. Later we perform robustness checks through several variations of Eq. (10). ${ }^{31}$

Our sample consists of 63 countries for which we have data for the variables used in our regressions described above. The list of countries is shown in Table 3. As can be seen, this list is a diversified group of countries from all parts of the world.

\section{Empirical Results}

Table 4 provides summary statistics for the variables used in the regressions described in the next 
Table 5 Corporate tax rate and strength of the legal system

\begin{tabular}{|c|c|c|c|c|}
\hline & (1) & (2) & (3) & (4) \\
\hline Legal & $\begin{array}{l}-3.324^{\star \star *} \\
(-3.25)\end{array}$ & $\begin{array}{l}-3.322^{* \star *} \\
(-3.25)\end{array}$ & $\begin{array}{l}-11.814^{* * *} \\
(-3.55)\end{array}$ & $\begin{array}{l}-11.814^{\star \star *} \\
(-4.47)\end{array}$ \\
\hline Lagged Ln (GDP) & $\begin{array}{l}0.593^{* * *} \\
(5.19)\end{array}$ & $\begin{array}{l}0.603^{* * *} \\
(5.17)\end{array}$ & $\begin{array}{l}-0.842^{*} \\
(-1.71)\end{array}$ & $\begin{array}{l}0.023 \\
(0.04)\end{array}$ \\
\hline Lagged GDP growth rate & $\begin{array}{l}0.148^{\star * *} \\
(2.75)\end{array}$ & $\begin{array}{l}0.161^{* * *} \\
(2.67)\end{array}$ & $\begin{array}{l}-0.041^{*} \\
(-1.96)\end{array}$ & $\begin{array}{l}-0.087^{* * *} \\
(-3.75)\end{array}$ \\
\hline Lagged debt/GDP & $\begin{array}{l}0.047^{\star \star \star} \\
(5.98)\end{array}$ & $\begin{array}{l}0.046^{\star * *} \\
(5.80)\end{array}$ & $\begin{array}{l}-0.021^{\star * *} \\
(-2.69)\end{array}$ & $\begin{array}{l}-0.022^{\star \star \star} \\
(-2.86)\end{array}$ \\
\hline Year & $\begin{array}{l}-0.340^{* * *} \\
(-7.36)\end{array}$ & & $\begin{array}{l}-0.273^{* \star *} \\
(-6.15)\end{array}$ & \\
\hline Year fixed effects & & Included & & Included \\
\hline Country fixed effects & & & Included & Included \\
\hline Adjusted $R$-square & 0.135 & 0.123 & 0.872 & 0.874 \\
\hline Number of observations & 861 & 861 & 861 & 861 \\
\hline
\end{tabular}

This table reports the coefficient estimates, and the level of statistical significance (***, $* *$, and * denote 1,5 , and $10 \%$ significance level, respectively) of an ordinary least-squares regression that includes an intercept term, where the dependent variable is the Corporate Tax rate of a country during 2003-2018. The independent variables are described in more detail in the paper in the "Legal systems and corporate taxes" section. The standard errors associated with the $t$-statistics are adjusted for heteroscedasticity.

few paragraphs. The dependent variable in our regressions, namely the corporate tax rate varies between $9 \%$ and $42 \%$, with an average of $26.61 \%$. The inference variable in our regressions, Legal ranges between 0.08 and 0.96 , with an average of 0.41 . The control variables used in our regressions are described above.

The results for our baseline specification as per Eq. (10) described above are shown in Column 1 of Table 5. We find strong evidence consistent with one of our central results (Proposition 8) and our framework. In particular, we find that a stronger legal system is associated with a lower corporate tax rate, as evidenced by the negative sign of the coefficient on Legal, and this effect is statistically significant at the $1 \%$ level. In addition, the coefficients on the control variables show that higher income countries, fast-growing countries, as well as countries with higher levels of government debt, are all associated with higher corporate tax rates. Interestingly, there has been a secular downtrend in the corporate tax rates as evidenced by the negative coefficient of the time-trend (i.e., Year) variable.

\section{Robustness Checks}

In this section, we examine the robustness of our baseline results. First, since statutory corporate taxes rates change rather infrequently, and to control for a potential endogeneity between statutory corporate tax rates and strength of the legal system, we run the regressions using a fixed effects model. Column 2 of Table 5 replaces the Year variable in Column 1 of Table 5 and runs the regression with year fixed effects. In Column 3 of Table 5, we augment Column 1 of Table 5 with country fixed effects. ${ }^{32}$ Inclusion of the country fixed effects in the regression significantly increases the explanatory power (i.e., an increase in the adjusted $R$-square from 0.135 in Column 1 of Table 5 to 0.872 in Column 3 of Table 5).

In Column 4 of Table 5, we replace the Year variable in Column 1 of Table 5 and run the regression with both year and country fixed effects. The results in Column 4 of Table 5 are almost identical to the results in Column 3 of Table 5, suggesting that the results are invariant to inclusion of a time-trend variable or year fixed effects. Overall, the evidence from columns 2-4 of Table 5 shows that the Legal variable continues to have a negative coefficient that is statistically significant at the $1 \%$ level in each of these specifications. This evidence provides support for a stronger legal system to be associated with a lower corporate tax rate as predicted by the model in our paper. In regressions that we subsequently run, we will include both year and country fixed effects.

Second, our paper has implications for tax compliance with reference to the strength of the legal system. Tax compliance is a feature of the quality of the legal system, whereby there will be less tax compliance in a weaker legal system. If weaker legal systems have a lower degree of tax compliance, it is possible that we find an inverse relationship between tax rates in general and the strength of 
Table 6 Corporate tax rate and components of strength of the legal system (includes year fixed effects and country fixed effects)

\begin{tabular}{|c|c|c|c|c|}
\hline & (1) & (2) & (3) & (4) \\
\hline Hon_Unc & $\begin{array}{l}-17.33^{* * *} \\
(-4.47)\end{array}$ & & & \\
\hline Affordable & & $\begin{array}{l}-9.984 \\
(-1.54)\end{array}$ & & \\
\hline Consistent & & & $\begin{array}{l}-12.54^{\star * *} \\
(-4.47)\end{array}$ & \\
\hline Confidence & & & & $\begin{array}{l}-15.14^{\star * *} \\
(-4.47)\end{array}$ \\
\hline Lagged Ln (GDP) & $\begin{array}{l}0.0228 \\
(0.04)\end{array}$ & $\begin{array}{l}0.0228 \\
(0.04)\end{array}$ & $\begin{array}{l}0.0228 \\
(0.04)\end{array}$ & $\begin{array}{l}0.0228 \\
(0.04)\end{array}$ \\
\hline Lagged GDP growth rate & $\begin{array}{l}-0.0867^{* * *} \\
(-3.75)\end{array}$ & $\begin{array}{l}-0.0867^{\star * *} \\
(-3.75)\end{array}$ & $\begin{array}{l}-0.0867^{* * *} \\
(-3.75)\end{array}$ & $\begin{array}{l}-0.0867^{\text {}} \\
(-3.75)\end{array}$ \\
\hline Lagged debt/GDP & $\begin{array}{l}-0.0224^{* *} \\
(-2.86)\end{array}$ & $\begin{array}{l}-0.0224^{* *} \\
(-2.86)\end{array}$ & $\begin{array}{l}-0.0224^{* *} \\
(-2.86)\end{array}$ & $\begin{array}{l}-0.0224^{\star *} \\
(-2.86)\end{array}$ \\
\hline Year fixed effects & Included & Included & Included & Included \\
\hline Country fixed effects & Included & Included & Included & Included \\
\hline Adjusted $R$-square & 0.874 & 0.874 & 0.874 & 0.874 \\
\hline Number of observations & 861 & 861 & 861 & 861 \\
\hline
\end{tabular}

This table reports the coefficient estimates, and the level of statistical significance $\left({ }^{* * *},{ }^{* *}\right.$, and ${ }^{*}$ denote 1,5 , and $10 \%$ significance level, respectively) of an ordinary least-squares regression that includes an intercept term, where the dependent variable is the Corporate Tax rate of a country during 2003-2018. The independent variables are described in more detail in the paper in the "Legal systems and corporate taxes" section. The standard errors associated with the $t$-statistics are adjusted for heteroscedasticity.

the legal system arising from social objectives with a target revenue base. However, in our model, the corporate tax rate (imposed only on the limited liability firm) is specifically designed to align the innovation incentives of the firm with social optimality. In other words, our prediction is on the corporate tax rate that is designed to curb the innovation aggressiveness of the limited liability firm.

We note that our Legal variable already includes a component that has an attribute that is related to tax compliance. We conjecture, based on the tax morale and trust literature, that the extent to which the legal system is honest and uncorrupt (hon_unc) is directly related to the trust in the legal system. For instance, Alm and Torgler (2006) show that a higher level of trust leads to a higher tax morale in that country (this in turn could result in lower tax avoidance, and hence greater tax compliance). In particular, they show that an increase in trust in the legal system or in parliament by one unit raises the share of persons indicating the highest tax morale by more than 3 percentage points. We test this by running the regression in Column 4 of Table 5 by replacing Legal with hon_unc - see column (1) of Table 6 . The coefficient on hon_unc is negative and statistically significant at the $1 \%$ level.

For completeness, we investigate whether the remaining three components have a similar negative relationship with the corporate tax rates, and hence whether they are important contributors to the strong negative relationship between corporate tax rates and the Legal variable. That is, we replace the Legal variable in Column 4 of Table 5 with each of these components separately. The results are tabulated in Table 6 columns (2) through (4). All components show a negative relationship with corporate tax rates, with two of the three variables statistically significant at the $1 \%$ level. Overall, Table 6 shows that all components are important and meaningful contributors of the Legal variable.

Third, we investigate how the negative relation between tax rates and legal system varies relative to innovative investment (as compared to old and tried investment). To proxy for the extent of innovative investment at the country level, we use the most recently available data on Global Innovation Index (https://www.globalinnovationindex. org/Home). The Global Innovation Index is the result of a collaboration between Cornell University, INSEAD, and the World Intellectual Property Organization (WIPO) as co-publishers, and their Knowledge Partners. According to this database, countries are classified into three separate categories: Innovation performance above expectations for level of development (Higher Innovation), Innovation performance in line with expectations for 
Table 7 Corporate tax rate and the strength of the legal system controlling for country-level innovation (includes year fixed effects and country fixed effects)

\begin{tabular}{lcc}
\hline Variable & & Corporate Tax rate (\%) \\
\cline { 2 - 3 } & Coeff. & $-9.42^{* * *}$ \\
\hline Legal & -14.345 & -0.32 \\
Lagged Ln (GDP) & -0.184 & $-3.73^{* * *}$ \\
Lagged GDP growth rate & -0.088 & $-3.17^{\star * *}$ \\
Lagged debt/GDP & -0.025 & -1.16 \\
Higher innovation & -0.723 & -0.37 \\
Medium innovation & -0.266 & Included \\
Year fixed effects & Included & \\
Country fixed effects & 0.873 & 861 \\
Adjusted $R$-square & 861 & \\
Number of observations &
\end{tabular}

This table reports the coefficient estimates, and the level of statistical significance $\left({ }^{* * *},{ }^{* *}\right.$, and ${ }^{*}$ denote 1,5 , and $10 \%$ significance level, respectively) of an ordinary least-squares regression that includes an intercept term, where the dependent variable is the Corporate Tax rate of a country during 2003-2018. The independent variables are described in more detail in the paper in the "Legal systems and corporate taxes" section. The standard errors associated with the $t$-statistics are adjusted for heteroscedasticity.

level of development (Medium Innovation) and Innovation performance below expectations (Lower Innovation). To analyze whether the negative relation between tax rates and legal system varies relative to innovative investment (relative to old and tried investment), we augment our baseline regression in Table 5 (i.e., column 4 that includes country and year fixed effects) with an additional indicator variables for Higher Innovation and Medium Innovation. ${ }^{33}$ The results, tabulated in Table 7 show that the negative relation between tax rates and legal system continues to hold even after we control for country-level indicators of innovative investment.

Finally, since our sample period overlaps with the global financial crisis, a likely concern is that while the financial crisis may have had its most adverse effect during 2007-2008, its effects have lingered well beyond 2007-2008. To address this concern, we augment our baseline regression in Table 5 (i.e., Column 4 that includes country and year fixed effects) with an additional control variables, namely Post Fin Crisis that takes a value of 1 in 2007 and beyond, and 0 otherwise, and an interactive variable Legal*Post Fin Crisis based on Legal and Post Fin Crisis. The results, shown in Table 8 are qualitatively unchanged. The coefficient on Legal continues to be negative and statistically significant at the $1 \%$ level.

There is a possibility of correlation between the country fixed effects and the legal variable. We examine whether such a correlation exists in our data. We don't find significant correlation between the country fixed effects and the legal variable. ${ }^{34}$ Nevertheless, for additional robustness, we also run our specification in Eq. (10) in first differences. The data on legal variable that we have used in Table 5 is from the World Business Environment Survey (WBES) conducted by the World Bank from 63 countries. This data does not have time variation since it is based on a one-time survey conducted in 1999. However, we have been able to secure another data source (with some time variation) from another World Bank survey conducted in multiple years on a measure of legal effectiveness that includes most of our original 63 countries in Table 5. See https://www.enterprisesurveys.org/en/ data for details.

In this database, we select two variables that are related to the strength of the legal regime for which we have time series data from 2006 to 2018. The first variable is called Business Licensing and Permits (BLP) and it refers to the percent of firms identifying business licensing and permits as their biggest obstacle to the current operations of their establishments. It has been documented that countries in which it is difficult to procure a business license or a permit usually have weak institutions, and correspondingly a weak and inefficient legal system. We construct a complement of this variable (1 - BLP) such that it corresponds to $\lambda$ the variable denoting the strength of the legal system in our framework. A second variable in this survey that we use is called Labor Regulations (LR). This variable refers to percent of firms identifying labor 
Table 8 Corporate tax rate, strength of the legal system and post financial crisis

\begin{tabular}{llc}
\hline Variable & & Corporate Tax rate (\%) \\
\cline { 2 - 3 } & Coeff. & $-3.68^{* * *}$ \\
\hline Legal & -14.787 & -0.09 \\
Lagged Ln (GDP) & -0.051 & $-3.59^{* * *}$ \\
Lagged GDP growth rate & -0.082 & $-2.85^{* * *}$ \\
Lagged debt/GDP & -0.022 & -0.07 \\
Post fin crisis & -0.057 & -1.30 \\
Legal * post fin crisis & -1.890 & Included \\
Year fixed effects & Included & 0.875 \\
Country fixed effects & 861 & \\
Adjusted $R$-square & Number of observations &
\end{tabular}

This table reports the coefficient estimates, and the level of statistical significance $\left({ }^{* \star *}\right.$, ${ }^{* *}$, and ${ }^{*}$ denote 1,5 , and $10 \%$ significance level, respectively) of an ordinary least-squares regression that includes an intercept term, where the dependent variable is the Corporate Tax rate of a country during 2003-2018. The independent variables are described in more detail in the paper in the "Legal systems and corporate taxes" section. The standard errors associated with the $t$-statistics are adjusted for heteroscedasticity.

Table 9 Corporate tax rate and the strength of the legal system using an alternative database (includes year fixed effects and country fixed effects)

\begin{tabular}{lcc}
\hline Variable & & Corporate Tax rate (\%) \\
\cline { 2 - 3 } & Coeff. & $-2.98^{* * *}$ \\
\hline Legal2 & -25.640 & $-2.04^{* *}$ \\
Lagged Ln (GDP) & -1.343 & $-1.76^{*}$ \\
Lagged GDP growth rate & -0.044 & -1.45 \\
Lagged debt/GDP & -0.017 & Included \\
Year fixed effects & Included & 0.932 \\
Country fixed effects & 525 & \\
Adjusted $R$-square & Number of observations &
\end{tabular}

This table reports the coefficient estimates, and the level of statistical significance ${ }^{* * *}, * *$, and $*$ denote 1,5 , and $10 \%$ significance level, respectively) of an ordinary least-squares regression that includes an intercept term, where the dependent variable is the Corporate Tax rate of a country during 2003-2018. The independent variables are described in more detail in the paper in the "Legal systems and corporate taxes" section. The standard errors associated with the $t$-statistics are adjusted for heteroscedasticity.

regulation as their biggest obstacle with the current operations of their establishments. ${ }^{35}$ As before, excessive labor protection, e.g., in socialist countries, is often accompanied by weak legal systems. We construct a complement of this variable (1-LR) such that it proxies for $\lambda$ the variable standing for the strength of the legal system in our framework.

Recall that our original legal variable (Legal) was constructed from a combination of four legal variables, namely hon_unc, affordable, consistent and confidence. Similarly, we combine both of our legal variables, namely (1-BLP) and (1-LR) to construct our new legal variable, Legal2 which now has variation across countries and across years. Using this variable, Legal2, we now run the specification in Eq. (10) replacing Legal with Legal2. The results are shown in Table 9. Similar to our results in Table 5, the coefficient of Legal2 is negative and statistically significant at the $1 \%$ level.

We next run first differences in corporate tax rates on first differences in Legal2 and first differences in the control variables as in Eq. (10). ${ }^{36}$ The results are shown in Table 10. As anticipated, we find a negative relationship between differences in tax rates and differences in legal quality. The coefficient of $\Delta$ Legal2 is negative and statistically significant at the $5 \%$ level. These results augment our results on the negative relationship between 
Table 10 Corporate tax rate and the strength of the legal system based on first-differences using an alternative database

\begin{tabular}{lll}
\hline Variable & & \multicolumn{1}{c}{ Corporate Tax rate (\%) } \\
\cline { 2 - 3 }$\Delta$ Legal2 & Coeff. & $t$-Stat. \\
$\Delta$ Lagged Ln (GDP) & -82.616 & $-2.36^{\star *}$ \\
$\Delta$ Lagged GDP growth rate & 2.788 & 1.67 \\
$\Delta$ Lagged debt/GDP & -0.157 & -1.18 \\
Adjusted $R$-square & -0.003 & -0.15 \\
Number of observations & 0.087 & 55 \\
\hline
\end{tabular}

This table reports the coefficient estimates, and the level of statistical significance ${ }^{* * *},{ }^{* *}$, and ${ }^{*}$ denote 1,5 , and $10 \%$ significance level, respectively) of an ordinary least-squares regression that includes an intercept term, where the dependent variable is the first difference of the Corporate Tax rate ( $\Delta$ Corporate Tax Rate) in the country during 2003-2018. The independent variables are also first differences (i.e., $\Delta$ Legal2, $\Delta$ Lagged Ln(GDP), $\Delta$ Lagged GDP Growth Rate, $\Delta$ Lagged Debt/GDP), as described in more detail in the paper the "Legal systems and corporate taxes" section. The standard errors associated with the $t$-statistics are adjusted for heteroscedasticity.

tax rates and legal strength based on our previous World Bank data.

\section{EXTENSIONS}

In this section, we discuss some issues related to the central analysis of the paper that have been ignored in the basic models thus far. We begin with a discussion of the consequences of relaxing the riskneutrality assumption. We then investigate the impact of personal wealth on our results.

\section{Risk Aversion}

In this subsection we examine the role of risk aversion. For example, corporate investor risk aversion (i.e., a higher discount rate for the firm than the social planner) raises the cut-off probability at which the corporation will invest in the innovation. This is because investor risk aversion would reduce the present value of the net cash flows to the firm in the success state.

Risk neutrality and a zero risk-free rate are assumed for simplicity and to abstract from discounting. We use this commonly made assumption to focus on incentive conflicts between social and private optimality. However, in this extension, we would like to discuss the consequences of relaxing the risk-neutrality assumption on the part of the investors (equity holders and debt holders who are capital suppliers to the firm), the decision-making manager, and the social planner. As to the risk aversion of the investors in the market, the pricing kernel in the underlying well-functioning capital market, and hence the valuation operator would change to reflect the degree of their risk-aversion. Since we are using the market value of the firm as the basis of private optimality, this would only change the computed market value and nothing else of essence. This is also in accord with the foundational corporate finance paradigm which is predicated on shareholder wealth maximization as an objective.

Since the above valuation paradigm takes into account that shareholders are well-diversified while the decision-making manager may not be, the riskaversion of the manager may turn out to be more important. In other words, a risk-averse manager (i.e., CEO) may take into account her under-diversified human capital risk in the innovation decision. Consequently, the risk-averse manager will take on the innovative project at a higher cut-off probability relative to the private optimality based on risk-neutral and/or value-maximizing shareholders. This problem can now be cast in the form of an agency cost resulting from the difference in risk-aversion of the manager vis-à-vis the well diversified shareholders. There are well-known solutions to this managerial risk-aversion problem using appropriate CEO compensation structures or corporate governance mechanisms. For example, the incentive of the risk-averse manager can be convexified through the use of restricted stocks, and executive stock options (See John and John (1993) and Jensen and Murphy (1990)). Finally, the social planner could be risk-averse with respect to the high social cost that depend on the idiosyncratic outcomes of innovation in the private sector. Conceptually, this would mean that the social objective function would use the expected utility rather than the expected value of the social cost outcomes. 


\section{Personal Wealth}

In this subsection we highlight the impact of the owners' wealth on the benefits and costs of limited liability. Wealth constraints at the corporation owner level can reduce the effective liability of unlimited liability corporations. For example, corporate owners who have no personal wealth are automatically liable for only the aggregate corporate cash flows. More specifically, if the owners combined personal $\mathrm{W}$ is such that:

$$
0<W<C_{L} \lambda,
$$

the costs that the unlimited liability corporation internalizes is now not $C_{L} \lambda$ but only $W .{ }^{37}$

Therefore, the benefits of opting for limited liability decrease as corporate owners are less wealthy. Effectively then, deficiencies in personal wealth limit the legal liability and reduce the benefits of corporate limited liability.

\section{CONCLUSIONS}

When private firms impose positive and negative externalities on society at large, the legal structure and the liability structure implied by the organizational form alter the sharing rule between the owners of a corporation and the non-financial claimants. Whether or not the private firm innovates more than the socially optimal level depends on several factors that we analyze, most importantly profitability of a successful innovation, its negative externalities, and its non-monetized social benefits.

It turns out that under certain conditions (i.e., $\phi>0)$, limited liability corporations innovate excessively. In this case, we show that corporate taxation can play an important role in aligning the private innovation policy with socially optimal level. Thus, taxes can be viewed as the price to be paid by corporations for limited liability. Corporations trade off the benefits of limited liability with the potential costs of corporate taxes. This, in turn, provides a rationale for the existence of entity-level double taxation (corporate taxes). Such a rationale was part of the legislative debate over the introduction of the tax in $1909 .{ }^{38}$

Our solution has implications for the debate on the mechanisms used for the resolution of the global financial crisis. The role of taxation can be viewed in the same manner as the government taking claims in the private firms. The government, in exchange for bailing out failing financial institutions, is known to have taken equity-like claims, such as preferred stock and warrants, as a mechanism for repaying the tax payer. In this respect, we note that corporate taxation plays two roles. First, corporate taxation of cash flows in profitable states works in a fashion similar to the government holding non-voting equity or warrants in the private firms in a setting of ex post resolution of crisis. Second, corporate taxation has ex ante incentive effects, since as we show, it can play a role in realigning the innovation incentives of private firms with the goals of the government. Thus, incentives are realigned in the right way without mandating specific innovation levels through invasive regulation.

On the other hand, successful innovations can bring large non-monetized benefits to the society at large. We provide several examples in the paper, including innovations curing cataclysmic diseases, such as cancer, coronavirus (COVID-19), and river blindness. In this case (i.e., $\phi<0)$, the private firms innovate less than the socially optimal level. Our analysis of the relevant institutional mechanisms includes subsidies, limitation of liabilities, and investment subsidies.

Our framework provides an explanation for the MNC strategies that arbitrage differences in legal liability structures and corporate taxes across national boundaries. MNCs may use these strategies to evade some of the constraints imposed by corporate taxes and legal liabilities in their home countries. This corresponds to our institutional mechanisms for the case when $\phi>0$. On the other hand, MNCs can also provide positive externalities, which corresponds to our analysis when $\phi<0$. In this case, the host country's social planner provides innovation incentives for MNCs when the required technology or capacity is not available locally. Host countries will provide various subsidies and investment incentives to make it attractive for MNCs to locate in the host country. Such innovation incentives are part of our framework and the associated institutional mechanisms for incentivizing innovation in the host country.

In our paper, we show that countries with poor legal structures, on an average, have higher corporate tax rates. ${ }^{39}$ This prediction of our model is also supported by our empirical analysis in the "Legal systems and corporate taxes: cross-country empirical evidence" section. We conduct several additional tests using different proxies for the strength of the legal system, and show that our main result is robust to the legal proxies that we use. Our 
relationship is also robust to inclusion of country and year fixed effects, and to the analysis of firstdifferences in the relevant variables. In particular, we conduct our empirical analysis using two different databases and document the negative relationship between tax rates and our proxies of legal strength.

The rationale for taxation in this paper would imply a stand against the repeal of double taxation through corporations. In addition, this view of taxation presents an interesting ingredient in analyzing social implications when countries compete for innovation and investment based on corporate tax incentives. Recently, the US Government took an important step towards improving US tax competitiveness. The Tax Cuts and Jobs Act was signed into law by President Donald J. Trump on Dec. 22, 2017. A major element of the tax reform includes cutting the highest marginal corporate income tax rate from $35 \%$ down to $21 \%$. An interesting question to analyze is the effect of corporate taxes on corporate innovation. Moreover, a related research question is the social impact of tax competition between countries that differ in legal strength, e.g., the United States vis-à-vis some of the European nations which have not yet lowered the corporate tax rate.

In the main model of this paper we have assumed that the strength of the legal system $(\lambda)$ in an economy is exogenously given, and the optimal institutions are designed using corporate taxation and organizational forms as the ingredients. Going beyond the conventional liability structures (limited and unlimited liability), we analyze the general liability structures in which firms are only held accountable for the part of the social costs that are assigned to them by the legal system. This opens up other interesting possibilities in which the social planner can discriminate among industries based on the positive externalities that they generate. Such differential corporate tax incentives and limitation of liability already exist in practice. For instance, the Price-Anderson Act (Public Law 85-256) limits liability from nuclear accidents. In recent times, the current administration in the United States has embarked on providing additional support to certain industries, such as coal mining, steel etc. through rolling back of regulation and imposition of tariffs. A current example is the stimulus package of $\$ 2$ trillion related to the coronavirus (COVID-19) that includes generous corporate subsidies.
In addition to providing a menu of liability structures, the social planner can also optimally choose, as an additional instrument, the strength of the legal enforcement $(\lambda)$. Although our framework is general enough to allow for an analysis of institutional design in which $\lambda$ is endogenously chosen by the social planner, such a task is left for future research.

\section{ACKNOWLEDGEMENTS}

The authors thank two anonymous referees, Editor-inChief, Alain Verbecke, and Consulting Editor, Sidney Gray, for their insightful comments and suggestions. We also thank William Allen, Yakov Amihud, Nittai Bergman, Utpal Bhattacharya, Jennifer Carpenter, Jeff Coles, Mihir Desai, Andrew Feldstein, Carola Friedman, Russ Hamilton, Sabrina Howell, Ravi Jagannathan, Yujin Jeong, Shane Johnson, Simi Kedia, Theresa Kuchler, Toomas Laarits, Mattia Landoni, C.F. Lee, Samuel Lee, Marcella Lucchetta, Stewart Myers, Stavros Panageas, Cecilia Parlatore, Loriana Pelizzon, Jim Poterba, N.R. Prabhala, Robert Richmond, Jay Ritter, Anthony Saunders, Marti Subrahmanyam, Tracy Wang, Bilge Yilmaz, and presentations at African Economic Research Consortium (AERC), NYU, MIT, New York Federal Reserve, Indiana University, Rutgers University, Fordham University, Georgia State University Young School of Public Policy, American University, SEC, University of Venice, Texas A\&M University, University of Amsterdam, Arizona State University, Bocconi University, University at Buffalo Alumni seminar, McGill University, University of Michigan, University of South Florida, the Hong Kong Polytechnic University, and the Conference on Financial Economics and Accounting for comments and/or discussions.

\section{NOTES}

${ }^{1}$ Thus, nonfinancial claimholders are defined broadly to include potential awardees of legal settlements resulting from future industrial accidents as well as current holders of jury claims in product liability suits.

${ }^{2}$ See for example, The Corporation: The Pathological Pursuit of Profit and Power by Joel Bakan or Gangs of America: The Rise of Corporate Power and the Disabling of Democracy by Ted Nace. 
${ }^{3}$ In our paper, "innovation" captures the spirit of deviating from the old and tried method which generates normal profits (normalized to zero) with probability 1 and instead invest in a risky project that generates a random cash flow. When the innovation succeeds, which happens with a probability $p$, the resulting cash flow is high. When the innovation fails, which happens with a probability $(1-p)$, the cash flow is low. The level of investment is fixed in our framework and innovation is different from overinvestment (i.e., where a firm invests more than the optimal level) in a risky technology.

${ }^{4}$ The existing corporate finance literature has focused on the conflict of interest among various classes of capital contributors to the corporation. The incentive effects of outstanding risky debt and the distortions in investment choices have been studied extensively. Modeling the scale or the riskiness of investment as "private" choices made by corporate insiders, it has been shown that risky debt induces underinvestment (compared to valuemaximizing levels) and risk-shifting (shifting into high-risk projects even at the expense of corporation value). See Jensen and Meckling (1976) and Myers (1977). However, even in the absence of any conflicts among holders of external financial claims, say in the case of an all-equity corporation, corporate limited liability induces conflict of interest between equity holders and non-financial claimholders (and more generally society at large).

${ }^{5}$ The view that taxation can be used to control a corporation's power to abuse stakeholders was, in fact, a primary motive to introduce taxation (see, for example, Kornhauser (1990)). Actually, in President Taft's message justifying the introduction of the corporate tax, the principal reason was that it enabled the federal government to exercise some degree of supervision, primarily by obtaining information about the business affairs of corporations, and more broadly by serving a regulatory function. "While the faculty of assuming a corporate form has been of the utmost utility in the business world, it is also true that substantially all of the abuses and all of the evils which have aroused the public to the necessity of reform were made possible by the use of this very faculty". See also Avi-Yonah (2004), Pechman (1987) and Desai, Dyck and Zingales (2007) for providing monitoring role for corporate taxation. In contrast, we focus on the incentive effect of corporate taxation on innovation policy of a limited liability firm.
${ }^{6}$ This refers to the tax levied on corporate profits in addition to personal taxes levied on its shareholders. Double-taxation has troubled economists. Indeed, as Stiglitz (1988, p.586) notes, "most economists cannot see any strong argument for the differential tax treatment." In our paper, corporate taxation is designed to align the innovation incentives of the limited liability corporations with social optimality. In other words, corporate tax is the price for the benefit of corporate limited liability.

${ }^{7}$ Our rationale is built on the foundation provided by La Porta et al. (1997, 1998) who had argued that legal traditions were typically introduced into various countries through conquest and colonization and, as such, were largely exogenous. In other words, while it is conceivable that countries may be able to make changes to their legal systems, we view that such a change in the strength of the legal system would be relatively slow, and hence the legal strength is likely to be largely exogenous in the short-run.

${ }^{8}$ We believe our approach does integrate the third of the three focal points highlighted by Henisz and Swaminathan (2008: 539) as being important for future researchers on institutions and IB. Relevant to our paper, though, are the "rules of the game" highlighted by Eden (2010: 175) as importantly influencing the private incentives of firms engaging in the economic activity of production, distribution, innovation and exchange (see also, North (1990)).

${ }^{9}$ In fact, offering limited liability rights to corporations is often cited as a landmark ruling that empowered the corporation to its "pathological pursuit of profits". See for example the op-ed piece "Reward but no risk" in New York Times, May 10, 2003. Quite early, it had been well recognized that limited liability was a mixed blessing and the implications of limited liability - the feature that the owners are not liable for any claims greater than the value of the corporation - were widely debated. In this debate, the concern for society is evident from the following observation in Hunt (1937): "There was a corporation and widespread conviction that unlimited liability was not only some safeguard against speculation, but also that general limitation, by allowing men to indulge in their spirit of adventure without endangering their fortunes would produce a sudden 
convulsion, a rush into all sorts of schemes [and society will be exposed to] the evils of inconsiderate enterprise and reckless speculation".

${ }^{10}$ Using the old and tried method involves an investment of I dollars that generates a cash flow whose discounted present value is I dollars. In other words, the project earns positive profits commensurate with the normal required rate of return. These profits, when discounted at the required rate of return, generate a present value of I dollars, and hence the project has an NPV equal to zero. In our benchmark model, this traditional technology is assumed not to produce any externalities, positive or negative, as discussed in detail in the "Nonfinancial claimants" subsection. The cash flows from this traditional technology will not be subject to corporate taxation in view of the fact that the project does not produce any externalities (see the "Limited liability" subsection). By the same token, the corporation is also exempted from any legal liabilities associated with doing business as discussed in the "Non-financial claimants" subsection. As we can see later, taxation and subsidies will be introduced as mechanisms that will align private innovation incentives with social optimality. See "The role of corporate taxation" and "The institutional design when $\mathrm{B}_{\mathrm{H}}$ is high" subsections for details.

${ }^{11}$ We abstract from any agency issues between managers and the shareholders of the corporation, and the role of incentive features of managerial compensation in addressing the public-private conflict (see, for instance, John, Saunders, Senbet, 2000).

${ }^{12}$ This rules out the possibility that contracts on innovation policy stating their probability of success are not possible. Incomplete contracting is a crucial feature of our model that captures the fact that writing and enforcing contracts that specify probability of success of innovations are not feasible. This feature would also preclude invasive regulation of innovation decisions made by the firm.

${ }^{13}$ See the "Risk aversion" subsection for a discussion of relaxing this assumption of risk-neutrality. Without any loss of generality, the risk-free rate is normalized to 0 .

${ }^{14}$ More generally, let the social costs and the nonmonetized benefits in each state be $C_{l}$ and $B_{l}$, where I denotes the state.

${ }^{15}$ In this state, the firm absorbs all the costs it imposes.
${ }^{16}$ Thus, here we assume that the aggregate personal wealth of the owners of the firm is sufficient to meet these legal claims. See the "Personal wealth" subsection for a discussion of the case where this assumption is relaxed.

${ }^{17}$ We note that there is a high degree of uncertainty regarding the social costs $C_{H}$ and $C_{L}$. For the purposes of our model, we assume that the social planner will come up with estimates of expected values of these costs based on historical experience. For example, Samet and Seo (2016) contain an insightful discussion of how the indirect costs related to medical care of affected victims of the nuclear accident were estimated.

${ }^{18}$ For details, see https://en.wikipedia.org/wiki/ Price\%E2\%80\%93Anderson_Nuclear_Industries_ Indemnity_Act.

${ }^{19}$ Scientists William C Campbell and Satoshi Omura have been awarded the Nobel prize for medicine for their discovery of a way to treat river blindness. They together discovered a group of compounds known as avermectins, the derivatives of which are used to treat and prevent river blindness. Their research led to the creation of ivermectin (brand name Mectizan ${ }^{\circledR}$ ) which is used to treat the disease in developing countries.

${ }^{20}$ As discussed in endnote 10 , the traditional technology will not be subject to corporate taxation in view of the fact that the project does not produce any externalities.

${ }^{21}$ In assuming that the taxable income equals $\left(H-C_{H}\right)$, we abstract from the details of many realistic features of the tax code, particularly deductions allowed for investment and R\&D, and sectorspecific investment tax credits. There is large heterogeneity in the depreciation tax shields allowed among the 63 countries used in our sample. In a recent study, Asen (2020) documents evidence consistent with this. The cumulative recovery over the life of the asset ranges from $41.7 \%$ in Chile to $100 \%$ in Estonia among the OECD countries. Similarly, in the EU countries, the depreciation allowances vary across type and life of assets. For example, according to the Common Corporate Tax Base (CCTB) proposal for European Union (EU) countries, for longlived assets, such as buildings, depreciation schedule allows an annual rate of $4 \%$. Even though we abstract from the heterogeneity with respect to the features of the tax code in our main theoretical model, in "Implications for multinational corporations" subsection, we consider MNC tax strategies that take advantage of this heterogeneity. 
${ }^{22}$ This effect of corporate taxation on innovation policy will be attenuated in the presence of deductions related to investment, such as depreciation tax shields. In our main model, we do not consider depreciation tax shields. Had we modelled a tax code that allows for a 100\% depreciation tax shield, and rederived the cut-off innovation policy, Eq. (5) would be replaced by the following expression:

$$
p_{T}=\frac{I}{\left(H-C_{H}-I\right)(1-T)+I}
$$

This innovation policy would continue to be a function of the corporate tax rate, $T$.

${ }^{23} \mathrm{Here}$, it is useful to consider the private firm to be an unlimited liability firm discussed in the "Unlimited liability" subsection. The unlimited liability firm is responsible for the social costs, $C_{H}$ in the successful state of the innovation and $C_{L}$ in the failure state of the innovation. In other words, the only difference between the private objective of value-maximization of the unlimited liability firm and the social planner's objective is that the unlimited liability firm does not take into account the nonmonetized social benefits $B_{H}$. Therefore, a dollar-for-dollar subsidy of $B_{H}$ given to the private firm fully aligns its innovation policy with the socially optimal one.

${ }^{24}$ Although our analysis deals with a dollar amount subsidy, $S^{*}$, a parallel analysis can formulate the subsidy as a fraction $\gamma^{*}$ of $H$, where $S^{*}=\gamma^{*} H$.

${ }^{25}$ For a survey of the literature on MNCs using a broader perspective, see Beugelsdijk and Mudambi (2013). For the role of MNCs in the global diversification, see Gande, Schenzler and Senbet (2009). For additional motivations underlying MNC strategies, see, Buckley and Casson (1998), Dunning and Lundan (2008), and Rugman and Verbeke (2003).

${ }^{26}$ Moreover, Ferdausy and Rahman (2009) provide other examples of incentives directly or indirectly provided by the host country.

${ }^{27}$ The newly enacted 2017 Tax Cuts and Jobs Act (TJCA) ignores the social consequences of externalities by MNCs and focuses on tax competitiveness. It is the most generous corporate tax reform in generations; it reduces the corporate tax rate from 35 to $21 \%$. There is evidence that MNCs have already began engaging in tax minimization strategies. In particular, our framework provides an explanation for some of the tax strategies implemented by MNCs to overcome the constraints of the institutional design (e.g., Albertus, Glover \& Levine, 2019 study how a change from a world- wide to a territorial tax system enacted under TCJA affects the incentives for U.S. multinationals to invest abroad). This idea has interesting policy implications for the regulation of domestic firms and MNCs.

${ }^{28}$ In conducting the above empirical analysis, we have implicitly assumed that the strength of the legal system is exogenous. Our rationale is built on the foundation provided by La Porta et al. (1997, 1998) who had argued that legal traditions were typically introduced into various countries through conquest and colonization and, as such, were largely exogenous. In other words, while it is conceivable that countries may be able to make changes to their legal systems, we view that such a change in the strength of the legal system would be relatively slow, and hence the legal strength is likely to be largely exogenous in the short-run.

${ }^{29} \mathrm{https} / / /$ home.kpmg/vg/en/home/services/tax1/ tax-tools-and-resources/tax-rates-online/corporatetax-rates-table.html.

${ }^{30}$ While we use an effective tax rate in our model, due to data limitations, we use the statutory rates as a proxy for effective tax rates in our empirical analysis in this study.

${ }^{31}$ As an alternative to the government debt to GDP, we also considered a gross credit to GDP variable as a control variable. In particular, we used "Domestic credit to private sector (\% of GDP)" from the World Development Indicators (WDI) database in lieu of the government debt to GDP variable in the regressions we run in this paper. The results are qualitatively unchanged, i.e., the Legal coefficient continues to be negative and statistically significant in all the regressions. The size of the sample was slightly smaller - the number of observations dropped from 861 to 820 . These results are available from the authors upon request.

${ }^{32}$ In our model, we focus on the incentive effect of corporate taxation on the innovation policy of the limited liability firm. Features of the national tax code, such as depreciation tax shields, expensing $\mathrm{R} \& \mathrm{D}$, and investment tax credits exist in our sample. We also find heterogeneity with respect to these tax provisions among the different countries. Our inclusion of country fixed effects will likely capture such cross-country differences in the tax code. We do find the evidence to be in support of the main predictions of our model.

${ }^{33}$ We drop the Lower Innovation indicator variable due to linear dependence, i.e., the three indicator variables relating to innovation add up to 1 . 
${ }^{34}$ Only two of 63 country fixed effects have a statistically significant correlation with the legal variable at the $5 \%$ level of significance, and the average $p$ value for whether a correlation between a country fixed effects and the legal variable is statistically significant is 0.49 .

${ }^{35}$ Maggioni, Santangelo and Koymen-Ozer (2019) investigate the role of local labor regulation on MNCs location decisions across different sectors and sub-national regions within a developing country.

${ }^{36} \mathrm{We}$ cumulate the first differences over the entire sample period since changes are rather infrequent: most countries have two or three surveys conducted during the entire sample period.

${ }^{37}$ The use of non-pecuniary forms of punishment, such as imprisonment, to hold the firm owners responsible would however, reduce the importance of personal wealth.

${ }^{38}$ As Avi-Yonah (2004) points out, Senator Cummins, an opponent of the proposed tax stated that: If this tax is intended not to create a revenue, but if it is

\section{REFERENCES}

Aguilera, R. V., \& Grogaard, B. 2019. The dubious role of institutions in international business: A road forward. Journal of International Business Studies, 50: 20-35.

Akamah, H., Hope, O. K., \& Thomas, W. B. 2018. Tax havens and disclosure aggregation. Journal of International Business Studies, 49(1): 49-69.

Albertus, J. F., Glover, B., \& Levine, O. 2019. Foreign investment of U.S. multinationals: the effect of tax policy and agency conflicts. Carnegie Mellon University Working Paper.

Alm, J., \& Torgler, B. 2006. Culture differences and tax morale in the United States and in Europe. Journal of Economic Psychology, 27(2): 224-246.

Anderson, D. 1982. Financing asbestos claims: Coverage issues, Manville's bankruptcy and the claims facility. Journal of Risk and Insurance, 54: 429-451.

Asen, E. 2020. Capital Cost Recovery across the OECD. Tax Foundation, 704. Retrieved April 8, 2020, from https:// taxfoundation.org/capital-cost-recovery-across-the-oecd2020/.

Avi-Yonah, R. S. 2004. Corporations, society and the state: A defense of the corporate tax. Virginia Tax Review, 90: 1193-1255.

Bakan, J. 2004. The corporation: The pathological pursuit of profit and power. New York: Free Press.

Bawlya, S. M. 2006. Foreign direct investment and technology spillovers: Evidence from panel data analysis of manufacturing firms in Zambia. Journal of Development Economics, 81: 514-526.

Beugelsdijk, S., \& Mudambi, R. 2013. MNEs as border-crossing MLEs: The role of discontinuities in geographic space. Journal of International Business Studies, 44(5): 413-426.

Buckley, P. J., \& Casson, M. J. 1998. Models of the multinational enterprise. Journal of International Business Studies, 29: 21-44.

Coase, R. H. 1960. The problem of social cost. Journal of Law and Economics, 3: 1-44.

Coase, R. H. 1991. The institutional structure of production. Lecture to the memory of Alfred Nobel. https://www.nobelprize. org/prizes/economic-sciences/1991/coase/lecture/. intended for the purpose of supervising and regulating corporations, that is quite a different proposition. I should like to know before we get through with this whether it is proposed through this tax to impose supervisory regulation upon all the corporations of the United States.

${ }^{39}$ In this paper, we do not examine how low corporate taxes may also provide incentives for multinationals to shift their realization of profits, cash flows or production across the world. See Akamah, Hope, and Thomas (2018) who present evidence that multinational companies with operations in tax havens tend to reduce the transparency of their tax-avoidance activities by aggregating their geographical disclosures. Ting and Gray (2019) illustrate that the tax avoidance motive of multinational firms can incentivize managers to locate profits in low-tax jurisdictions without affecting the locations of their real operations.

Cohen, W. M., \& Leventhal, D. A. 1990. Absorptive capacity: A new perspective on learning and innovation. Administrative Science Quarterly, 35: 128-152.

Desai, M. A., Dyck, A., \& Zingales, L. 2007. Theft and taxes. Journal of Financial Economics, 84(3): 591-623.

Djankov, S., La Porta, R., Lopez-de-Silanes, F., \& Shleifer, A. 2003. Courts. Quarterly Journal of Economics, 118: 453-517.

Dunning, J. H., \& Lundan, S. M. 2008. Multinational enterprises and the global economy (2nd ed.). Cheltenham: Edward Elgar.

Eden, L. 2010. Lifting the veil on how institutions matter in IB research. Journal of International Business, 41: 175-177.

Ferdausy, S., \& Rahman, M. S. 2009. Impact of multinational corporations on developing countries. The Chittagong University Journal of Business Administration., 25: 117-138.

Gan, Y., \& Qiu, B. 2019. Escape from the USA: Government debt-to-GDP ratio, country tax competitiveness, and USOECD cross-border M\&As. Journal of International Business Studies, 50: 1156-1183.

Gande, A., Schenzler, C., \& Senbet, L. W. 2009. Valuation effects of global diversification. Journal of International Business Studies, 40: 1515-1532.

Hall, P. A., \& Soskice, D. W. 2001. Varieties of capitalism: The institutional foundations of comparative advantage. Oxford: Oxford University Press.

Henisz, W., \& Swaminathan, A. 2008. Institutions and international business. Journal of International Business, 39(4): 537-539.

Hernando, Y., Colwell, K., \& Wright, B. D. 2016. Doing well while fighting river blindness: The alignment of a corporate drug donation programme with responsibilities to shareholders. Tropical Medicine \& International Health, 21(10): 1304-1310.

Hunt, B. 1937. The development of the business corporation in England, 1800-1867. Cambridge: Harvard University Press.

Jackson, G., \& Deeg, R. 2008. Comparing capitalisms: Understanding institutional diversity and its implications for international research. Journal of International Business, 39(4): 540-561. 
Jensen, M., \& Meckling, W. 1976. Theory of the firm: Managerial behavior, agency costs and ownership structure. Journal of Financial Economics, 3: 305-360.

Jensen, M., \& Murphy, K. J. 1990. Performance pay and topmanagement incentives. Journal of Political Economy, 98(2): 225-264.

John, T., \& John, K. 1993. Top-management compensation and capital structure. Journal of Finance, 48(3): 949-974.

John, K., Saunders, A., \& Senbet, L. W. 2000. A theory of bank regulation and management compensation. Review of Financial Studies, 13: 95-125.

Kornhauser, M. E. 1990. Corporate regulation and the origins of the corporate income tax. Indiana Law Journal, 66(1): 53-136.

La Porta, R., Lopez-de-Silanes, F., Shleifer, A., \& Vishny, R. W. 1997. Legal determinants of external finance. Journal of Finance, 52: 1131-1150.

La Porta, R., Lopez-de-Silanes, F., Shleifer, A., \& Vishny, R. W. 1998. Law and finance. Journal of Political Economy, 106: 1113-1155.

Liu, Z. 2008. Foreign direct investment and technology spillovers: Theory and evidence. Journal of Development Economics, 85: 176-193.

Maggioni, D., Santangelo, G. D., \& Koymen-Ozer, S. 2019. MNEs' location strategies and labor standards: The role of operating and reputational considerations across industries. Journal of International Business Studies, 50: 948-972.

Malik, A. R., Rehman, C. A., Ashraf, M., \& Abbas, R. Z. 2012. Exploring the link between foreign direct investment, multinational enterprises and spillover effects in developing economies. International Journal of Business and Management, 7: 230-240.

Myers, S. 1977. Determinants of corporate borrowing. Journal of Financial Economics, 5: 147-175.

Nace, T. 2003. Gangs of America: The rise of corporate power and the disabling of democracy. San Francisco: Berrett-Koehler.

Narula, R. 2002. Innovation systems and 'inertia' in R\&D location: Norwegian firms and the role of systemic lock-in. Research Policy, 31: 795-816.

North, D. C. 1990. Institutions, institutional change, and economic performance. Cambridge: Cambridge University Press.

Pechman, J. A. 1987. Tax reform: Theory and practice. Journal of Economic Perspectives, 1: 11-28.

Rugman, A. M., \& Verbeke, A. 2003. Extending the theory of the multinational enterprises: Internalization theory and strategic management perspectives. Journal of International Business Studies, 34: 125-137.

Samet, J. M., \& Seo, J. 2016. The financial costs of the Chernobyl nuclear power plant disaster: A review of the literature. University of Southern California; Green Cross Switzerland: $49 . \quad$ http://www.greencross.ch/uploads/media/2016 chernobyl_costs_report.pdf. Accessed 11 August 2019.

Stiglitz, J. 1988. Economics of the public sector. New York: W. Norton and Company.

The Dodd-Frank Wall Street Reform and Consumer Protection Act (Pub.L. 111-203, H.R. 4173), July 21, 2010.

Ting, A., \& Gray, S. J. 2019. The rise of the digital economy: Rethinking the taxation of multinational enterprises. Journal of International Business Studies, 50: 1656-1667.

Verbeke, A. 2019. The JIBS 2018 Decade Award: Comparing capitalisms: Understanding institutional diversity and its implications for international business. Journal of International Business, 50: 1-3.

\section{APPENDIX: PROOFS}

Proposition 1 Proof is provided below the Proposition 1 in the "Corporate limited liability and corporate taxation" section.
Proposition 2 A straightforward comparison of the relevant cut-off probabilities in Eqs. (1) and (3), implies the result. We also obtain $p_{L}<p_{s}$ is equivalent to $\Phi>0$.

Proposition 3 Equating $p_{T}$ in Eq. (5) to $p_{S}$ in Eq. (1) and simplifying yields the given expression for the optimal tax rate $T^{*}$. The comparative statics results with respect to $C_{L}$ and $p_{L}$ follow readily from the form of the expression for $T^{*}$. For $\Phi>0, \Phi$ is decreasing in $B_{H}$ and hence $T^{*}$ is decreasing in $B_{H}$.

Proposition 4 Equating $p_{L}$ in Eq. (3) to $p_{S}$ in Eq. (1) and simplifying yields the expression for the optimal subsidy $S^{*}$ given in Proposition 4. Rearranging, $S^{*}$ can also be written as

$$
S^{*}=\frac{\left[B_{H}-\frac{C_{L}\left(H-C_{H}-I\right)}{I}\right]}{\left[\frac{C_{L}}{I}+1\right]} .
$$

The numerator of $S^{*}$ is smaller than $B_{H}$ and the denominator is greater than 1 . Therefore $S^{*}$ is strictly less than $B_{H}$.

Proposition 5 In addition to the limitation of liability in the state of failure of the innovation, there is an additional limitation of liability such that the liability in the success state of the innovation is only $f C_{H}$, which is equivalent to a subsidy of $(1-f) C_{H}$. Therefore, the optimal subsidy $\hat{S}$ now required is lower than $S^{*}$ by an amount $(1-f) C_{H}$. The inequalities follow in a straight-forward manner.

Proposition 6 Substitute $\alpha^{*}=1-\frac{p_{s}}{p_{L}}$ into the innovation policy of the limited liability firm to obtain $p_{L}\left(\alpha^{*}\right)=\frac{I\left(1-\alpha^{*}\right)}{\left(H-C_{H}\right)}=p_{s}$. The innovation policy of the limited liability firm is equal to the socially optimal level.

Proposition 7 A straight-forward comparison of the relevant cut-off probabilities in Eqs. (6) and (8), and rearranging terms implies the result.

Proposition 8 Equation (9) shows directly that the socially optimal tax rate is decreasing in $\lambda$. An alternate way of looking at this is that the socially optimal tax rate $T_{s}(\lambda)$ is an increasing function of $\left(p_{S}-p_{L}\right)$, the difference between the socially optimal innovation policy and the innovation policy of the limited liability corporation. Since $p_{S}$ is independent of $\lambda$ and $p_{L}$ is increasing in $\lambda,\left(p_{S}-p_{L}\right)$ is decreasing in $\lambda$. Therefore, the socially optimal tax rate $T_{s}(\lambda)$ is decreasing in $\lambda$.

Proposition 9 Given the tax rate $T_{s}(\lambda)$, corporations in the legal system $\lambda$ will find that their firm 
value as a limited liability firm (implementing the privately optimal innovation policy) will exceed their firm value as an unlimited liability firm (implementing its privately optimal innovation policy). Hence, the privately optimal organizational form turns out to be the limited liability organizational form. Of course, the subsequent privately optimal innovation policy will coincide with the socially optimal innovation policy (by design).

\section{ABOUT THE AUTHORS}

Amar Gande is an Associate Professor of Finance at the Cox School of Business, Southern Methodist University. He previously was a faculty member at Vanderbilt University. He holds a Ph.D. in finance from New York University's Stern School of Business. His award-winning research has been published in leading finance and international business journals, such as the Journal of Finance, Journal of Financial Economics, Review of Financial Studies, Journal of Financial and Quantitative Analysis, and Journal of International Business Studies. He is an editorial review board member at the Journal of International Business studies. His current research focuses on issues related to international finance and banks, such as the externalities of MNCs, and the implications of COVID-19 for banks.

Kose John is the Charles William Gerstenberg Professor of Banking and Finance at New York University, Stern School of Business. He has been a visiting professor at the University of Chicago, Columbia University, Temple University, and Institut d'Etudes Politiques de Paris (Sciences Po). He has won several awards, including the Batterymarch Fellowship in 1983 and the Jensen Prize for the best paper published in 2000 in the Journal of Financial Economics. He has been on the Nomination Committee for the Nobel Prize in Economics since 2016. His recent research interests include FinTech, Blockchain economics, corporate bankruptcy, dividend policy, corporate governance, topmanagement compensation, institutions and innovation. He has published over 110 research articles. He has mentored 106 doctoral students. Vinay B. Nair is the Founder and Chairman of The TIFIN Group, a fintech venture platform focused on driving better investor outcomes by building fintech companies that will shape the future of investor experience. A serial entrepreneur, investor, and academic, Vinay has started, is an advisor, or board member in several companies in financial services. Vinay has founded numerous companies linking investments and technology (55ip, Magnifi, MIO, Positivly, Louise) as well as run a quantitative hedge fund (Ada Investments). As a finance faculty member at Wharton, with teaching experience at schools such as MIT and Columbia, he focuses on venture capital, private equity, and entrepreneurship. His academic background includes a Ph.D. in Financial Economics from the Stern School of Business at NYU, and a Bachelors of Technology from the Indian Institute of Technology, Madras.

Lemma W. Senbet is the William E. Mayer Chair Professor of Finance at University of Maryland and former Executive Director/CEO of African Economic Research Consortium, with research interests spanning corporate finance and international finance. He has received numerous recognitions for his impact on the profession. He has been Director of American Finance Association and past President of Western Finance Association. He is Fellow of Financial Management Association International for his career-long distinguished scholarship. He was inducted into Financial Economists Roundtable, a distinguished group of world-wide financial economists. He has held associate editorships and editorial positions at over a dozen journals, including the Journal of Finance, Journal of International Business Studies, and Journal of Financial and Quantitative Analysis. He has been on the Nominating Group for the Nobel Prize in Economic Science. Professor Senbet has advised World Bank, IMF, UN, and agencies around the globe on financial sector reform issues. He is a member of the Brookings AGI Distinguished Advisory Group and of the Board of Hartford Funds.

Publisher's Note Springer Nature remains neutral with regard to jurisdictional claims in published maps and institutional affiliations. 